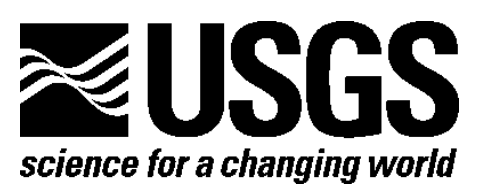

Semiautomatic Approaches to Account for 3-D Distortion of the Electric Field From Local, Near-Surface Structures in 3-D Resistivity Inversions of 3-D Regional Magnetotelluric Data

By Brian D. Rodriguez

Open-File Report 2017-1007

U.S. Department of the Interior U.S. Geological Survey 


\section{U.S. Department of the Interior RYAN K. ZINKE, Secretary}

\section{U.S. Geological Survey William Werkheiser, Acting Director}

U.S. Geological Survey, Reston, Virginia: 2017

For more information on the USGS—-the Federal source for science about the Earth, its natural and living resources, natural hazards, and the environment-visit http://www.usgs.gov/ or call 1-888-ASK-USGS (1-888-275-8747).

For an overview of USGS information products, including maps, imagery, and publications, visit http://store.usgs.gov/.

Any use of trade, firm, or product names is for descriptive purposes only and does not imply endorsement by the U.S. Government.

Although this information product, for the most part, is in the public domain, it also may contain copyrighted materials as noted in the text. Permission to reproduce copyrighted items must be secured from the copyright owner.

Suggested citation:

Rodriguez, B.D., 2017, Semiautomatic approaches to account for 3-D distortion of the electric field from local, nearsurface structures in 3-D resistivity inversions of 3-D regional magnetotelluric data: U.S. Geological Survey OpenFile Report 2017-1007, 25 p., https://doi.org/10.3133/ofr20171007.

ISSN 2331-1258 (online) 


\section{Contents}

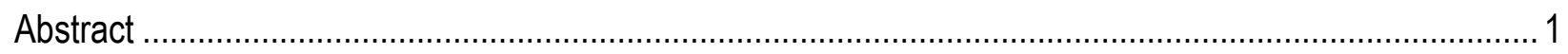

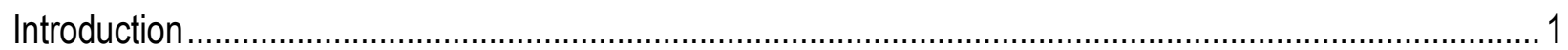

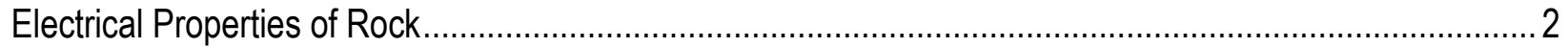

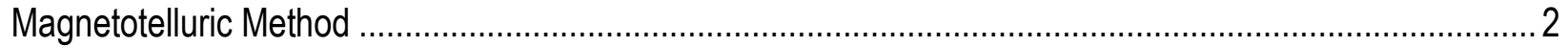

3-D Resistivity Model Build ......................................................................................................

3-D Resistivity Inversion Approaches ............................................................................................ 4

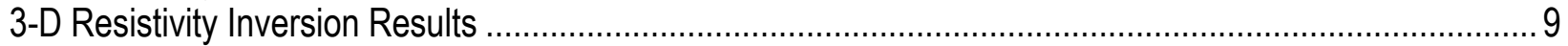

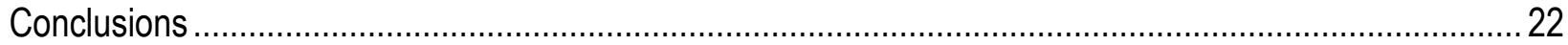

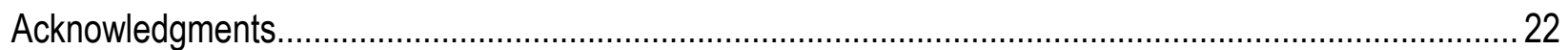

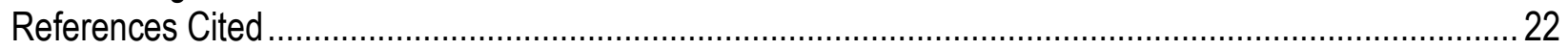

\section{Figures}

1. Three-dimensional resistivity forward model (250-meter XY cell size) depth slices......................... 4

2. Three-dimensional resistivity forward model (250-meter XY) data ............................................ 6

3. Mesh sensitivity test three-dimensional resistivity forward model (50-meter XY) ...........................

4. Mesh sensitivity test three-dimensional resistivity forward model (50-meter XY) data..................... 8

5. Three-dimensional inversion model (400 ohm-meters initial resistivity, 250-meter XY)

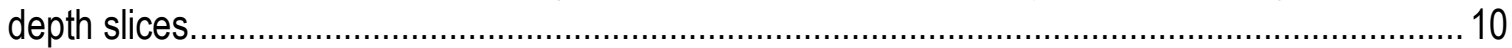

6. Three-dimensional inversion model (400 ohm-meters initial, 250-meter XY) data........................ 11

7. Three-dimensional inversion model (100 ohm-meters initial, 250-meter XY) depth slices.............. 12

8. Three-dimensional inversion model (100 ohm-meters initial, 250-meter XY) data......................... 13

9. Three-dimensional inversion model ( 100 ohm-meters initial, 50-meter XY) depth slices................ 14

10. Three-dimensional inversion model (100 ohm-meters initial, 50-meter XY) data......................... 15

11. Three-dimensional high-frequency inversion model (100 ohm-meters initial, 50-meter XY)

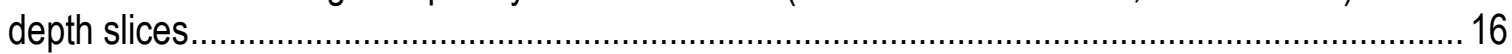

12. Three-dimensional high-frequency inversion model (100 ohm-meters initial, 50-meter XY) data ... 17

13. Three-dimensional a priori inversion model (50-meter XY) depth slices ..................................... 18

14. Three-dimensional a priori inversion model (50-meter $X Y)$ data ................................................. 19

15. Three-dimensional less smooth inversion model (50-meter XY) depth slices...............................20

16. Three-dimensional less smooth inversion model (50-meter XY) data.......................................... 21

\section{Table}

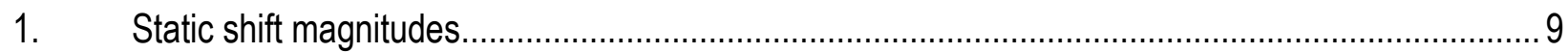

\section{Conversion Factors}

International System of Units to U.S. customary units

\begin{tabular}{lll}
\hline \multicolumn{1}{c}{ Multiply } & \multicolumn{1}{c}{ By } & \multicolumn{1}{c}{ To obtain } \\
\hline meter $(\mathrm{m})$ & 3.281 & foot $(\mathrm{ft})$ \\
kilometer $(\mathrm{km})$ & 0.6214 & mile $(\mathrm{mi})$ \\
\hline
\end{tabular}




\title{
Semiautomatic Approaches to Account for 3-D Distortion of the Electric Field From Local, Near-Surface Structures in 3-D Resistivity Inversions of 3-D Regional Magnetotelluric Data
}

\author{
By Brian D. Rodriguez
}

\begin{abstract}
This report summarizes the results of three-dimensional (3-D) resistivity inversion simulations that were performed to account for local 3-D distortion of the electric field in the presence of 3-D regional structure, without any a priori information on the actual 3-D distribution of the known subsurface geology. The methodology used a 3-D geologic model to create a 3-D resistivity forward ("known") model that depicted the subsurface resistivity structure expected for the input geologic configuration. The calculated magnetotelluric response of the modeled resistivity structure was assumed to represent observed magnetotelluric data and was subsequently used as input into a 3-D resistivity inverse model that used an iterative 3-D algorithm to estimate 3-D distortions without any a priori geologic information. A publicly available inversion code, WSINV3DMT, was used for all of the simulated inversions, initially using the default parameters, and subsequently using adjusted inversion parameters. A semiautomatic approach of accounting for the static shift using various selections of the highest frequencies and initial models was also tested. The resulting 3-D resistivity inversion simulation was compared to the "known" model and the results evaluated. The inversion approach that produced the lowest misfit to the various local 3-D distortions was an inversion that employed an initial model volume resistivity that was nearest to the maximum resistivities in the near-surface layer.
\end{abstract}

\section{Introduction}

Geophysical studies of complex three-dimensional (3-D) geologic problems require solutions that employ 3-D geophysical modeling. Assumptions involved in one-dimensional (1-D) and twodimensional (2-D) solutions for 3-D structure or 3-D local distortion produce model artifacts (that is, overestimations or underestimations) of target depths that result in false geologic interpretations of the 1-D or 2-D geophysical model. Researchers attempting to alleviate the ambiguity in 1-D and 2-D interpretations of magnetotelluric data have developed a number of 3-D algorithms (Smith and Booker, 1991; Mackie and Madden, 1993; Newman and Alumbaugh, 2000; Zhdanov and others, 2000; Sasaki, 2001, 2004; Zhdanov, 2002; Siripunvaraporn and others, 2004, 2005; Sasaki and Meju, 2006; Gribenko and Zhdanov, 2007; Mackie and others, 2007; Han and others, 2008; Avdeev and Avdeeva, 2009; Siripunvaraporn and Egbert, 2009; Gribenko and others, 2010; Siripunvaraporn and Sarakorn, 2011; Egbert and Kelbert, 2012; Kelbert and others, 2014). These efforts have also encouraged the acquisition 
of an increasing number of 3-D arrays of magnetotelluric data because collection of array data, as opposed to profile data, is well suited to 3-D inversion modeling.

Solving for 3-D distortion needs to be done when modeling magnetotelluric data. Distortion of regional electromagnetic fields, especially electric fields, by local features or structures that generate local electric and magnetic fields distorts magnetotelluric data (biased upward or downward), which can result in erroneous resistivity models. Distortion of magnetotelluric data lacks a formal definition, however, it fundamentally "... means that the observed electromagnetic fields include effects due to features that are outside the scope of the experiment or the interpretation, either too small or too large or of higher dimensionality that distort the regional electromagnetic fields that one wishes to observe ..." (Jones, 2012, p. 219). The distortion of regional magnetic fields falls off rapidly with increasing time, whereas distortion of regional electric fields in 1-D or 2-D cases, otherwise known as static shift (Weidelt and Chave, 2012), is frequency independent and persists to the longest periods (Jiracek, 1990; Jones, 2012). Distortion removal techniques exist (see Jones [2012] for extensive evaluation), but they are problematic in 3-D as the effects of distortion are not frequency independent (Jones, 2011).

In 2-D inversions, Berdichevsky and others (2003) found that inclusion of the vertical transfer function (the Tipper) helps diminish distortion of the electric field caused by local, near-surface inhomogeneities. These local 3-D distortions strongly affect the impedance tensor that is used in an inverse model, but not all surveys include the vertical magnetic field measurements.

In 3-D inversions, Ledo and others (1998) presented a solution for determining the local 2-D distortion when the regional resistivity structure is 3-D, but the case of local 3-D distortion over 3-D regional structure remains elusive. This report summarizes the results of 3-D resistivity inversion simulations that were conducted with the intent of accounting for local 3-D distortion of the electric field in the presence of 3-D regional structure without any a priori information on the actual 3-D distribution of the known subsurface geology other than the simulated magnetotelluric response.

\section{Electrical Properties of Rock}

Electromagnetic geophysical methods detect variations in the electrical properties of rock units - in particular, electrical resistivity in units of ohm-meters (ohm-m) or its inverse, electrical conductivity, in units of siemens per meter. Electrical resistivity can be correlated with geologic units on the surface and at depth by using lithologic and resistivity logs to provide a 3-D picture of subsurface geology. In the upper crust, the resistivities of geologic units largely depend upon their fluid content, pore-volume porosity, interconnected fracture porosity, and the presence of conductive minerals (such as clay, and less frequently, graphitic carbon and metallic minerals). Fluids in the pore spaces and fracture openings, especially saline fluids, can increase electrical conductivity in an otherwise electrically resistive rock matrix by orders of magnitude (Keller and Frischknecht, 1966; Hearst and Nelson, 1985; Keller, 1987; Palacky, 1987; Hallenburg, 1998). At greater depths, higher temperatures cause increased ion mobility, which increases fluid conductivity, and in turn, reduces the bulk resistivity (Hallenburg, 1998). Tables of electrical resistivity for a variety of rocks, minerals, and geological environments may be found in Palacky (1987) and Keller (1989).

\section{Magnetotelluric Method}

The magnetotelluric method is a passive, ground-based, electromagnetic geophysical technique that investigates the distribution of electrical resistivity (or its inverse, electrical conductivity) below the surface at depths of tens of meters to tens of kilometers (Vozoff, 1991) by measuring time variations in the Earth's natural electric and magnetic fields. Worldwide lightning activity at frequencies of about 
1-10,000 hertz and geomagnetic micropulsations at frequencies of $0.001-1$ hertz provide the main source of signals used by the magnetotelluric method. Electromagnetic waves propagate vertically in the Earth when the very large resistivity contrast between the air and the Earth causes a vertical refraction of electromagnetic waves at the Earth's surface (Vozoff, 1972).

In the magnetotelluric method, the horizontal components of the electric and magnetic fields are recorded in two orthogonal directions; the vertical magnetic field component is also commonly recorded. The resulting time-series signals are converted to complex cross spectra by using fast Fourier transform techniques and least-squares, cross-spectral analysis (Bendat and Piersol, 1971) to solve for a tensor transfer function. The cross spectra are then used to derive tensor-apparent resistivities and phases. If one assumes that the Earth consists of a two-input, two-output linear system in which the orthogonal magnetic fields are input and the orthogonal electric fields are output, then a transfer function can be calculated that relates the observed electric fields to the magnetic fields.

The magnetotelluric method is well suited for studying complicated geological environments because the electric and magnetic field transfer functions are sensitive to both vertical and horizontal variations in resistivity. High-resolution, shallow-subsurface characterization is possible for closely spaced magnetotelluric stations, but the resolution of the subsurface decreases for deeper measurements and for widely spaced stations. The method is thus capable of establishing whether the measured electric and magnetic field data are responding to subsurface rock bodies of effectively one, two, or three dimensions. An introduction to the magnetotelluric method and references for a more advanced understanding are contained in Dobrin and Savit (1988) and Vozoff (1991).

For a 2-D Earth with subsurface resistivity that is assumed to vary with depth and in one horizontal direction, the magnetotelluric fields can be decoupled into transverse electric and transverse magnetic modes. Two-dimensional resistivity modeling is generally computed to fit both modes. Before it is converted to apparent resistivity and phase, the tensor is normally rotated parallel to geologic strike. When the geology satisfies the 2-D assumption, the magnetotelluric data for the transverse electric mode are assumed to represent the electric field oriented along geologic strike and the data for the transverse magnetic mode are assumed to represent the electric field oriented across the strike.

In the 3-D case, the solution requires solving for the full impedance tensor for each frequency because the resistivity varies in the $\mathrm{X}, \mathrm{Y}$, and $\mathrm{Z}$ directions. In addition, decoupling into two modes, as in the 2-D case, is not possible because the diagonal elements are nonzero at any given rotation angle (Miensopust, 2010).

\section{3-D Resistivity Model Build}

A complex 3-D geologic model (based on well data and geologic cross sections at Pahute Mesa, Nevada) that includes local 3-D distortion over 3-D regional structure was used as input to a 3-D resistivity forward model. The 3-D geologic model is composed of volcanic composite units containing a complex mix of lava flow aquifers and tuff confining units. Construction details of the 3-D geologic model are described in Fenelon and others (2010). Bulk-average resistivities, based on induction resistivity logs, range from about $200 \mathrm{ohm}-\mathrm{m}$ to about $700 \mathrm{ohm}-\mathrm{m}$ for the resistive lava-flow aquifers, and range from about $60 \mathrm{ohm}-\mathrm{m}$ to about $100 \mathrm{ohm}-\mathrm{m}$ for the tuff confining units. Details of converting the 3-D geologic model into a 3-D resistivity model are described in Rodriguez and Sweetkind (2015). The 3-D forward modeling algorithm of Mackie and others (1994), as implemented in GeoSystem's WinGLink (version 2.20.02) software (http://www.slb.com/services/seismic/geophysical_processing_characterization/seismic_reservoir_chara cterization/electromagnetics/emsoftware/winglink.aspx), was used to build the 3-D resistivity model. The 3-D resistivity model fine-mesh grid used a 250 -meter $(\mathrm{m})$ by $250-\mathrm{m}$ by $50-\mathrm{m}$ (XYZ) cell size from 
0 -m to 2,400-m depth with a station spacing of $500 \mathrm{~m}$ (fig. 1). From 2,400-m depth to 100-kilometer $(\mathrm{km})$ depth, the horizontal fine-mesh grid remained at $250 \mathrm{~m}$ by $250 \mathrm{~m}$ but the vertical cell size increased nominally by a factor of 2 for each deeper layer until the deepest layer thickness of $50 \mathrm{~km}$. The horizontal cell size outside of the fine-mesh grid also increased nominally by a factor of 2 to the largest horizontal cell size of $100 \mathrm{~km}$. The full 3-D resistivity model covered a $380-\mathrm{km}$ by $380-\mathrm{km}$ by $100-\mathrm{km}$ volume occupying more than 70,000 cells. The calculated magnetotelluric response of the 3-D resistivity forward ("known") model was then used as simulated-observed magnetotelluric data for input into a homogeneous $400 \mathrm{ohm}-\mathrm{m}$ 3-D resistivity model that used an iterative 3-D algorithm to invert the simulated data. A synthetic, relative Gaussian noise-level error of 2.5 percent of the impedance magnitude was applied to the synthetic data.
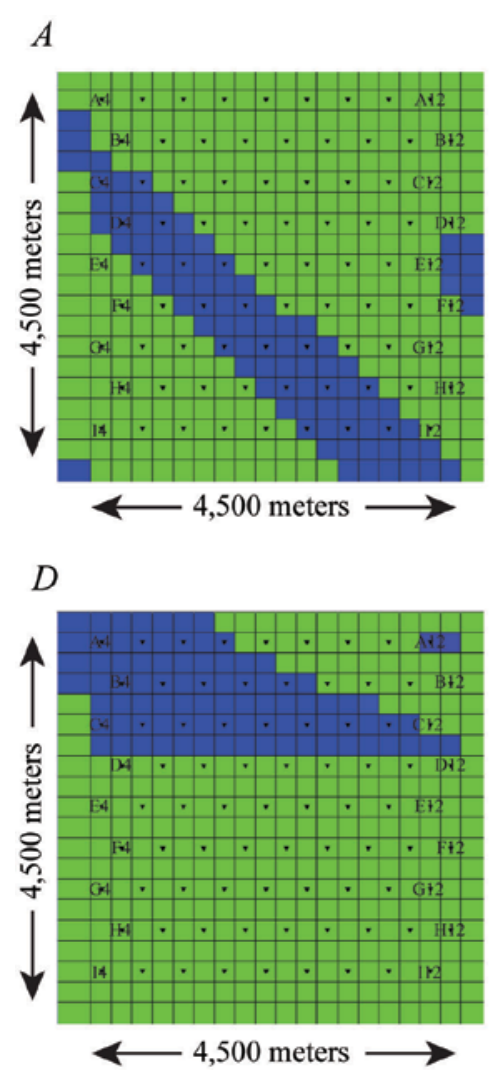

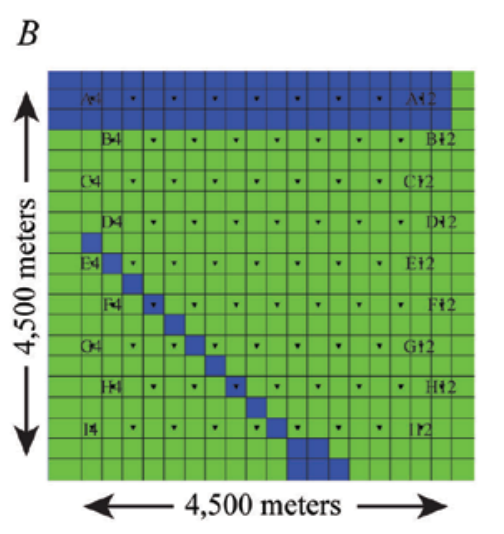

$E$

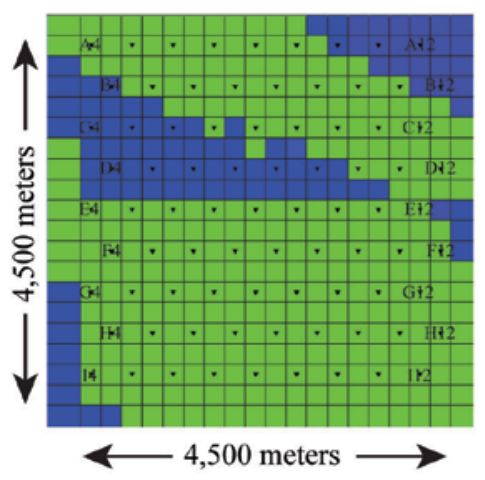

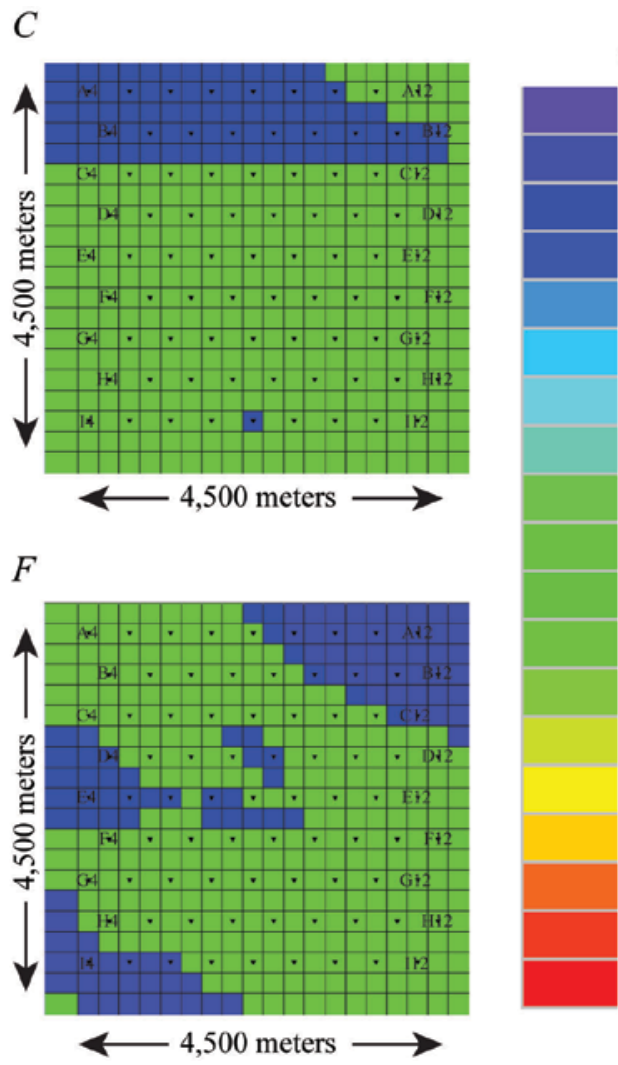

ohm-m

483

425

370

323

281

245

214

186

163

142

124

108

94

82

71

62

54

Figure 1. Three-dimensional resistivity forward model (250-meter [m] XY cell size) depth slices. Black labels within cells are simulated magnetotelluric stations. A) 0- to 50-m depth. B) 50- to 100-m depth. C) 100- to 150-m depth. D) 150- to 200-m depth. E) 200- to 250-m depth. F) 250- to 300-m depth. (ohm-m, ohm-meters)

\section{3-D Resistivity Inversion Approaches}

Several inversion approaches were tested to determine if a semiautomatic approach could correctly account for local 3-D distortion of the electric field in 3-D regional magnetotelluric data. The different approaches tested were

- Comparing lower to higher initial model resistivity volume to evaluate the importance of the initial model resistivity in accounting for near-surface local 3-D structures. 
- Using both coarse-grid and fine-grid meshes to evaluate inversion cell size sensitivity to local 3-D structures.

- Comparing inverting all of the frequencies simultaneously with a two-step approach to evaluate whether the two-step approach improved the likelihood of accounting for local 3-D distortion in the near-surface layer. The two-step approach involves initially inverting only the highfrequency data and then using the resulting inversion as the initial model into a second, a priori model and inverting all of the frequencies.

- Adjusting the smoothing parameters of the inversion to produce a less smooth model to increase the likelihood of producing a model with greater horizontal resistivity variations in the nearsurface layer to help account for the local 3-D structures.

The 3-D inversion modeling program, WSINV3DMT (version 1.0.0) (http://mucc.mahidol.ac.th/ scwsp/wsinv3dmt/), of Siripunvaraporn and others (2005), employing all of the default program parameters, was used to invert the homogeneous $400 \mathrm{ohm}-\mathrm{m} 3-\mathrm{D}$ resistivity model. This model required 6 gigabytes (GB) of computer memory and about 3 weeks of computation time for 5 iterations of all 8 real and imaginary diagonal and off-diagonal tensor elements for 11 evenly spaced frequencies $(1,000-0.01$ hertz) on a 3.5 gigahertz (GHz) Intel Xeon W3690 processor, 64-bit workstation computer with $24 \mathrm{~GB}$ of installed memory operating under 64-bit Linux. Frequencies were selected to span the entire magnetotelluric response (fig. 2) of the "known" model, but were also capped to a maximum number of frequencies that were inverted to reduce the long inversion times. 

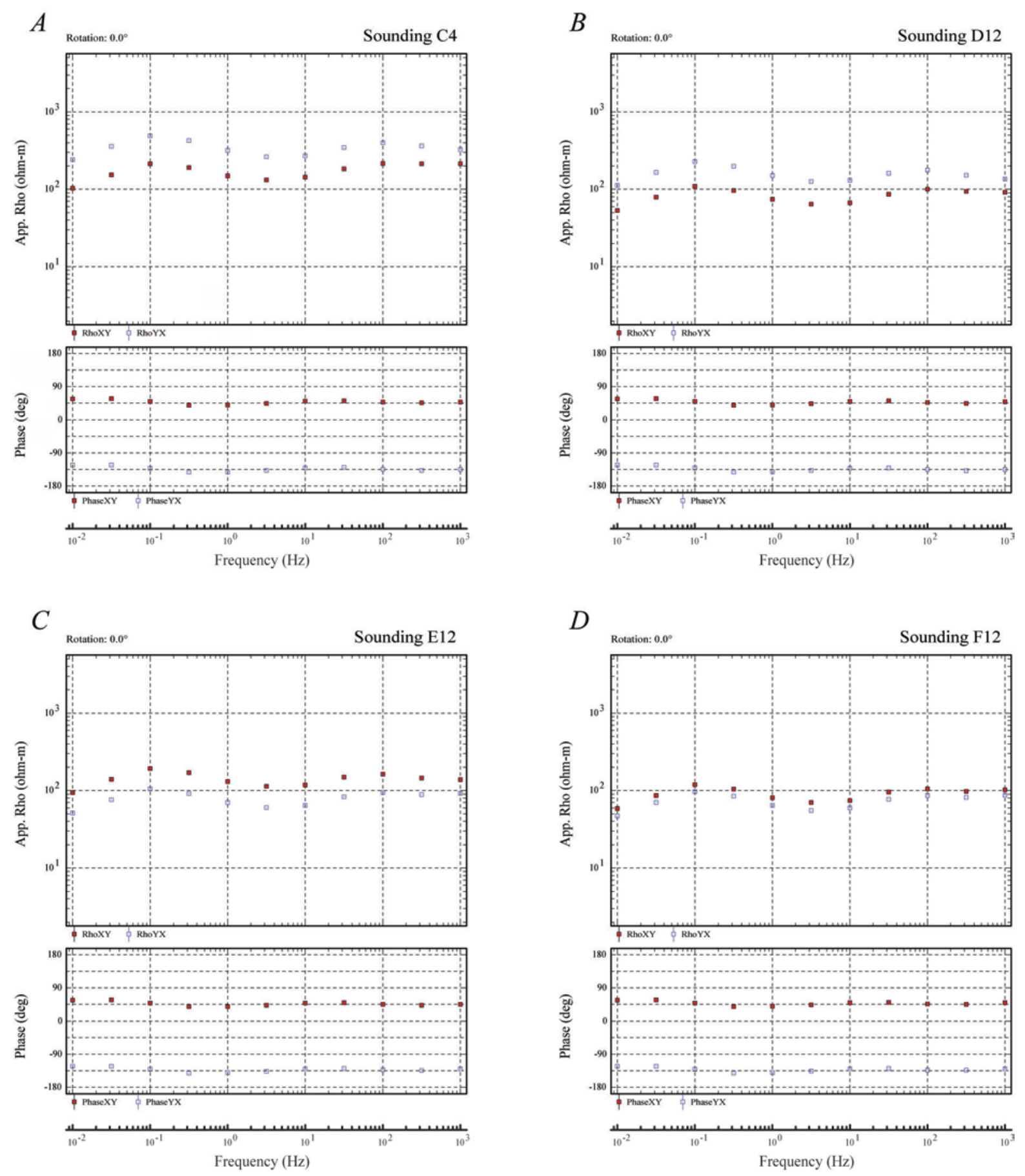

Figure 2. Three-dimensional (3-D) resistivity forward model (250-meter XY cell size) resistivity and phase data. App Rho is apparent resistivity. Phase is in degrees (deg). Red and blue square symbols are the 3-D simulated observed $X Y$ and $Y X$ data, respectively. A) Magnetotelluric station C4. B) Magnetotelluric station D12. C) Magnetotelluric station E12. D) Magnetotelluric station F12. (Hz, hertz; ohm-m, ohm-meters)

To evaluate the importance of the initial model resistivity volume in accounting for near-surface local 3-D structures, an inversion using the same mesh as the $400 \mathrm{ohm}-\mathrm{m}$ 3-D resistivity inversion was 
executed, but $100 \mathrm{ohm}-\mathrm{m}$ was used as the initial model resistivity to approximate the apparent highfrequency resistivity of a number of stations (fig. 2).

To test the fine-mesh cell-size sensitivity of the inversion program in accounting specifically for local 3-D distortion of the electric field, an additional 3-D resistivity model was constructed by scaling the fine mesh of the model and using the same relative resistivity distribution. A smaller XY cell size $(50 \mathrm{~m}$ by $50 \mathrm{~m}$ ) was used and a smaller station spacing of $100 \mathrm{~m}$ in the fine-mesh grid was employed (fig. 3). The vertical cell thickness was the same as the coarse-grid model discussed previously. The horizontal cell size, outside of the fine-mesh grid, also increased nominally by a factor of 2 until the largest horizontal cell size of $100 \mathrm{~km}$. The full 3-D resistivity model covered a $380-\mathrm{km}$ by $380-\mathrm{km}$ by $100-\mathrm{km}$ volume occupying more than 88,000 cells. The calculated magnetotelluric response of this $3-\mathrm{D}$ resistivity forward model (fig. 4) was then used as simulated observed magnetotelluric data for input into a homogeneous $100 \mathrm{ohm}-\mathrm{m}$ 3-D resistivity model that used an iterative 3-D algorithm to invert the simulated data. A synthetic, relative Gaussian noise-level error of 2.5 percent of the impedance magnitude was also applied to these synthetic data. This model required 12 GB of computer memory and about 4 months of computation time for 5 iterations of all 8 real and imaginary diagonal and offdiagonal tensor elements for 18 evenly spaced frequencies $(6,000-0.01$ hertz). The additional higher frequencies (greater than 1,000 hertz) were included to help resolve the smaller-scale variations in horizontal resistivity that were made possible with the smaller XY model cell size.
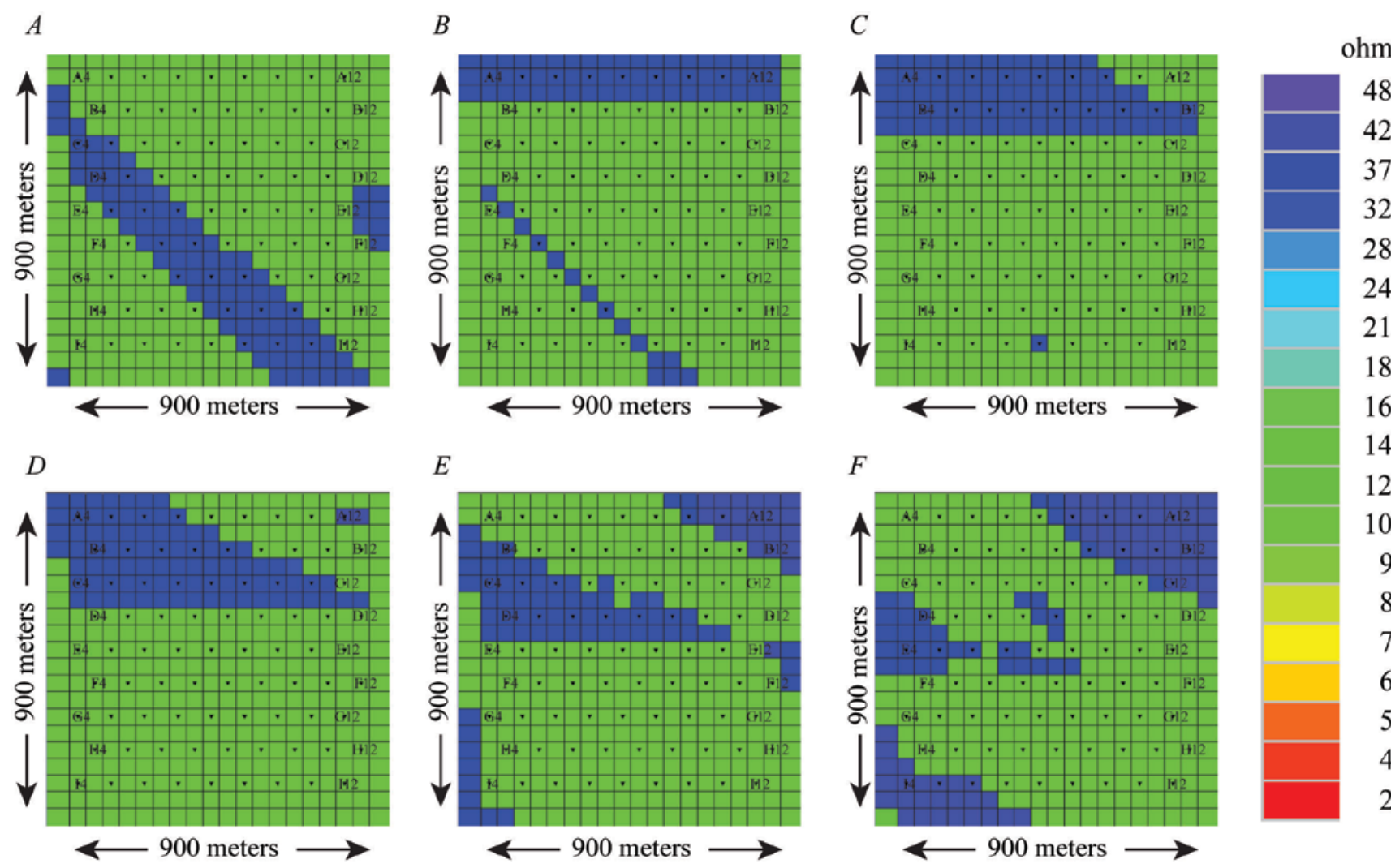

483
425
370
323
281
245
214
186
163
142
124
108
94
82
71
62
54
47
22

Figure 3. Mesh sensitivity test three-dimensional resistivity forward model (50-meter [m] XY cell size) depth slices. Black labels within cells are simulated magnetotelluric stations. A) 0- to 50-m depth. B) 50- to 100-m depth. C) 100 - to $150-\mathrm{m}$ depth. D) 150 - to $200-\mathrm{m}$ depth. E) 200- to 250-m depth. F) 250- to 300-m depth. (ohm-m, ohmmeters) 

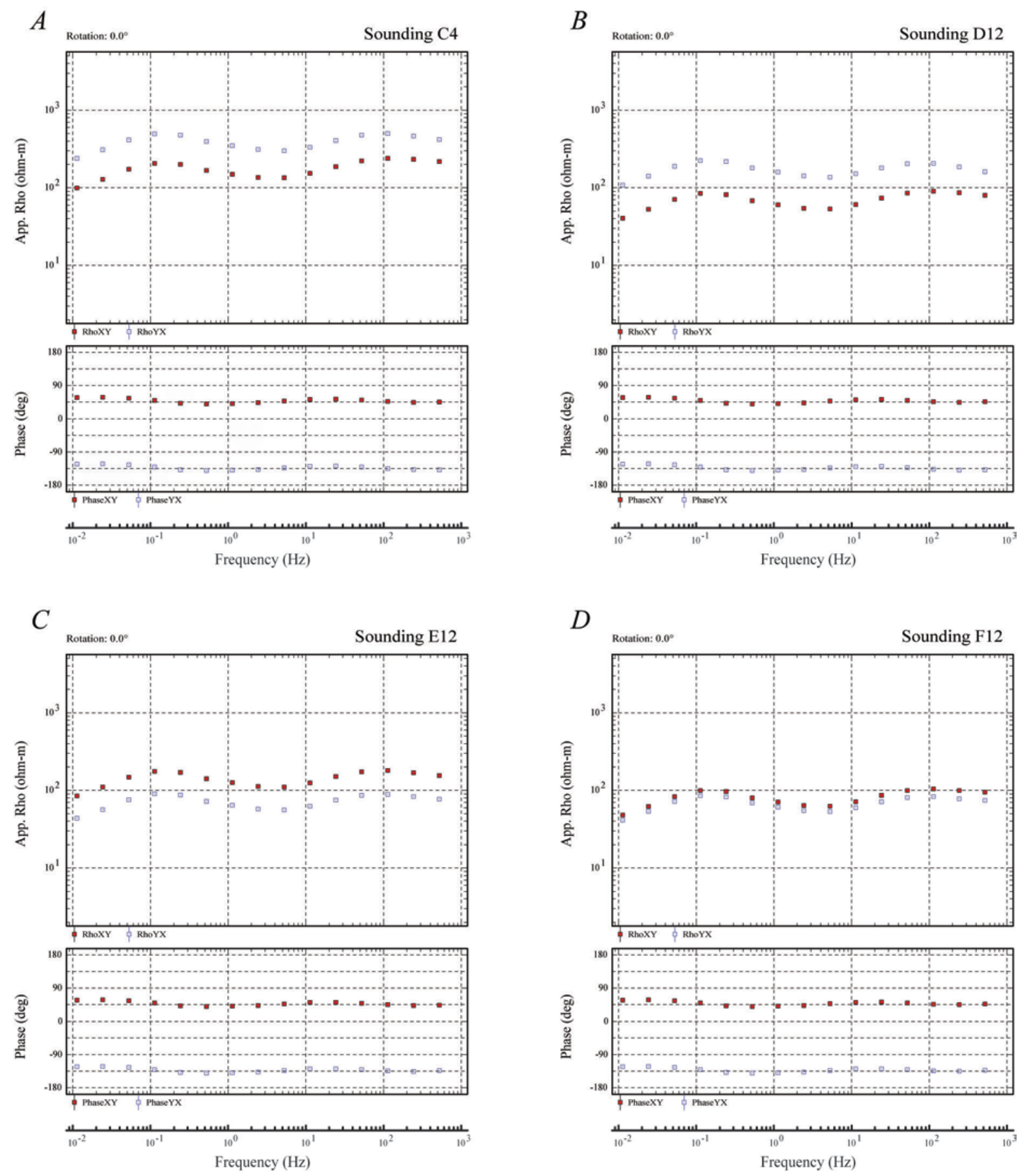

Figure 4. Mesh sensitivity test three-dimensional (3-D) resistivity forward model (50-meter XY cell size) resistivity and phase data. App Rho is apparent resistivity. Phase is in degrees (deg). Red and blue square symbols are the 3-D simulated observed $X Y$ and $Y X$ data, respectively. A) Magnetotelluric station C4. B) Magnetotelluric station D12. C) Magnetotelluric station E12. D) Magnetotelluric station F12. (Hz, hertz; ohm-m, ohm-meters)

To test the sensitivity of the inversion program to account for local 3-D distortion of the electric field when employing only the highest frequencies, another resistivity model using the $100 \mathrm{ohm}-\mathrm{m}$ smaller XY cell size was inverted using only frequencies higher than 100 hertz. This model required 
$11 \mathrm{~GB}$ of computer memory and about 5 weeks of computation time for 15 iterations of all 8 real and imaginary diagonal and off-diagonal tensor elements for 17 evenly spaced frequencies $(8,000-0.01$ hertz). The 15th inversion model was then used as an initial model for the full-frequency range inversion to test the approach of employing an a priori model derived from the highest frequencies as input for a full-frequency range inversion in accounting for local 3-D distortion. This model required 12 GB of computer memory and about 4 months of computation time for 5 iterations of all 8 real and imaginary diagonal and off-diagonal tensor elements for 18 evenly spaced frequencies $(6,000-0.01$ hertz).

To test the sensitivity of the different smoothness parameters of the inversion program in accounting for local 3-D distortion of the electric field, another resistivity model using the $100 \mathrm{ohm}-\mathrm{m}$ smaller XY cell size was inverted using a less smooth model covariance time step of 1 (default is 5) but employing the default model length scales $(0.1,0.1,0.1)$. The Lagrange multiplier was also reduced to a starting value and step size of 0.2 and 0.1 , respectively (default is 1.0 and 0.5 , respectively). This model required $12 \mathrm{~GB}$ of computer memory and about 4 months of computation time for 5 iterations of all 8 real and imaginary diagonal and off-diagonal tensor elements for 18 evenly spaced frequencies $(6,000-0.01$ hertz).

\section{3-D Resistivity Inversion Results}

In the "known" coarse-mesh model (fig. 1), magnetotelluric stations C4, D12, E12, and F12 (fig. 2) have the largest local 3-D distortion in the XY and YX components (0.184-, 0.167-, 0.165-, and 0.064-decade, respectively) (table 1). Other stations (A4, B4, D4, E4, and I12) were also in close proximity to surface-layer, 3-D boundaries, but were near 3-D axes of symmetry and thus had much smaller distortion.

Table 1. Static Shift Magnitudes.

[100-c, coarse mesh 100 ohm-meters (ohm-m) inversion; 100-f, fine mesh 100 ohm-m inversion; 400, 400 ohm-m inversion; A priori, high-frequency a priori inversion; Dec, decade $=\log \mathrm{XY}$ apparent resistivity-log YX apparent resistivity; Delta=modulus of observed (Obs) decade-model decade; High, high-frequency inversion; Less, less smooth inversion parameters; Obs-c, coarse mesh observed data; Obs-f, fine mesh observed data]

\begin{tabular}{|c|c|c|c|c|c|c|c|c|c|c|c|c|c|c|}
\hline Station & $\begin{array}{l}\text { Obs-c } \\
\text { Dec }\end{array}$ & $\begin{array}{l}400 \\
\text { Dec }\end{array}$ & $\begin{array}{c}400 \\
\text { Delta }\end{array}$ & $\begin{array}{c}100-c \\
\text { Dec }\end{array}$ & $\begin{array}{l}100-c \\
\text { Delta }\end{array}$ & $\begin{array}{l}\text { Obs-f } \\
\text { Dec }\end{array}$ & $\begin{array}{l}100-f \\
\text { Dec }\end{array}$ & $\begin{array}{l}100-f \\
\text { Delta }\end{array}$ & $\begin{array}{l}\text { High } \\
\text { Dec }\end{array}$ & $\begin{array}{l}\text { High } \\
\text { Delta }\end{array}$ & $\begin{array}{c}\text { A priori } \\
\text { Dec }\end{array}$ & $\begin{array}{l}\text { A priori } \\
\text { Delta }\end{array}$ & $\begin{array}{l}\text { Less } \\
\text { Dec }\end{array}$ & $\begin{array}{l}\text { Less } \\
\text { Delta }\end{array}$ \\
\hline $\mathrm{C} 4$ & 0.184 & 0.120 & 0.064 & 0.106 & 0.078 & 0.257 & 0.179 & 0.079 & 0.027 & 0.230 & 0.211 & 0.046 & 0.299 & 0.042 \\
\hline E12 & 0.165 & 0.191 & 0.026 & 0.189 & 0.024 & 0.293 & 0.342 & 0.049 & 0.159 & 0.133 & 0.390 & 0.097 & 0.433 & 0.140 \\
\hline F12 & 0.064 & 0.078 & 0.014 & 0.071 & 0.006 & 0.094 & 0.084 & 0.010 & 0.016 & 0.077 & 0.086 & 0.008 & 0.149 & 0.055 \\
\hline
\end{tabular}

The default settings of WSINV3DMT (Siripunvaraporn and others, 2005) were used for the initial inversion parameters of the initial homogeneous $400 \mathrm{ohm}-\mathrm{m}$ volume model ("400" in table 1), which resulted in a decrease in the total root mean square (RMS) error from 7.2180 to a total RMS error of 0.5681 after five iterations. Figure 5 illustrates the 3-D resistivity inversion result for the shallow layers. The simulated observed magnetotelluric data and the computed magnetotelluric response of the fifth inversion iteration are shown in figure 6. The local 3-D structure in the surface layer (fig. $5 \mathrm{~A}$ ) of this model $(0-50 \mathrm{~m})$ is the major contributor to the static shift response. The 3-D structure below the surface layer (figs. $5 B-5 F$ ) has a much smaller contribution to the static shift magnitude. Although the inversion achieved a good approximation to the static shift at stations C4, D12, E12, and F12 (0.064-, 
0.011-, 0.026-, 0.014-delta, respectively) (table 1), the overall resistivity is overestimated in the surface layer (compare fig. $1 A$ with fig. $5 A$ ).
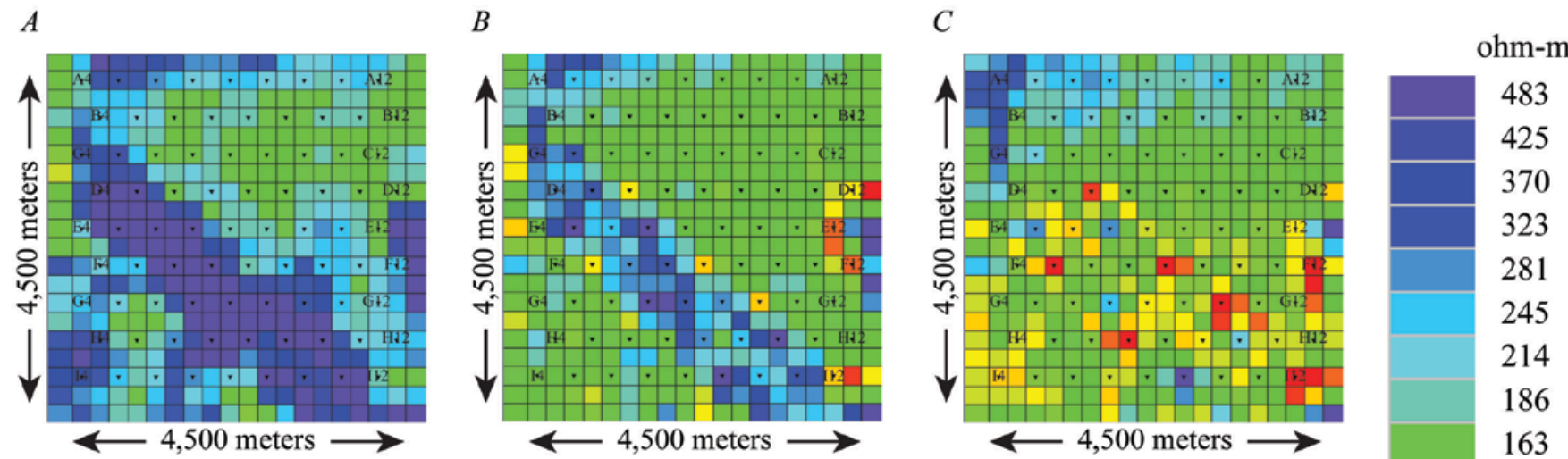

$D$

E
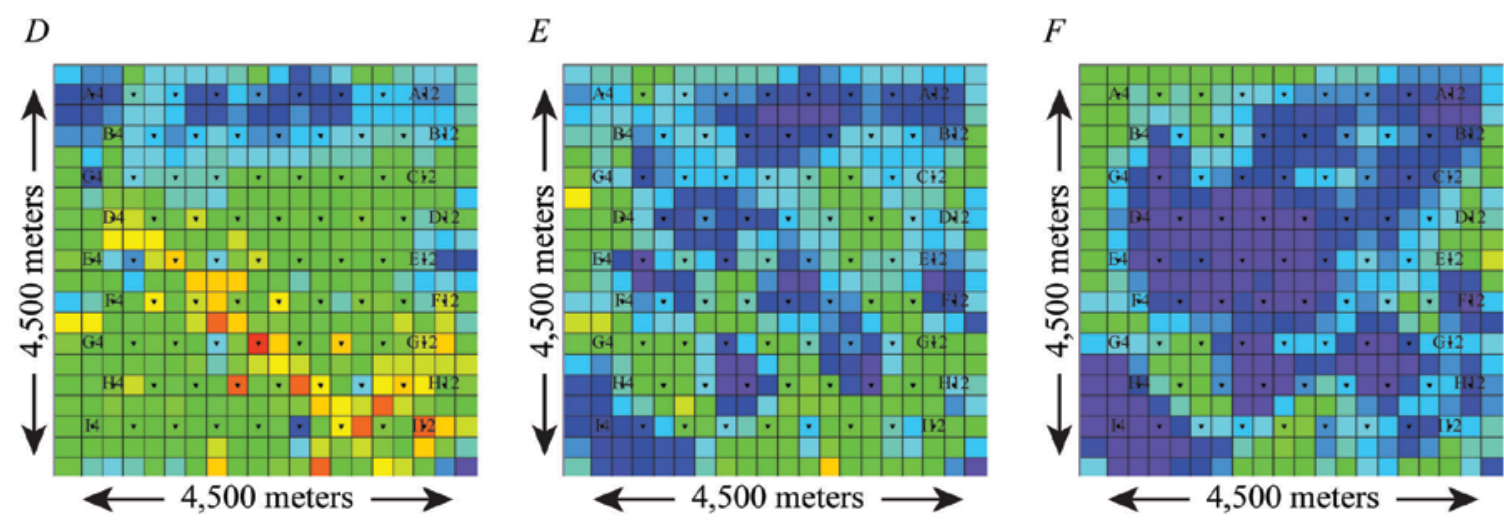

483

425

370

323

281

245

214

186

163

142

124

108

94

82

71

62

54

47

22

Figure 5. Three-dimensional inversion model (400 ohm-meters [ohm-m] initial resistivity, 250-meter [m] XY cell size) depth slices. Black labels within cells are simulated magnetotelluric stations. A) 0- to 50-m depth. B) 50- to 100-m depth. C) 100- to 150-m depth. D) 150- to 200-m depth. E) 200- to 250-m depth. F) 250- to 300-m depth. 

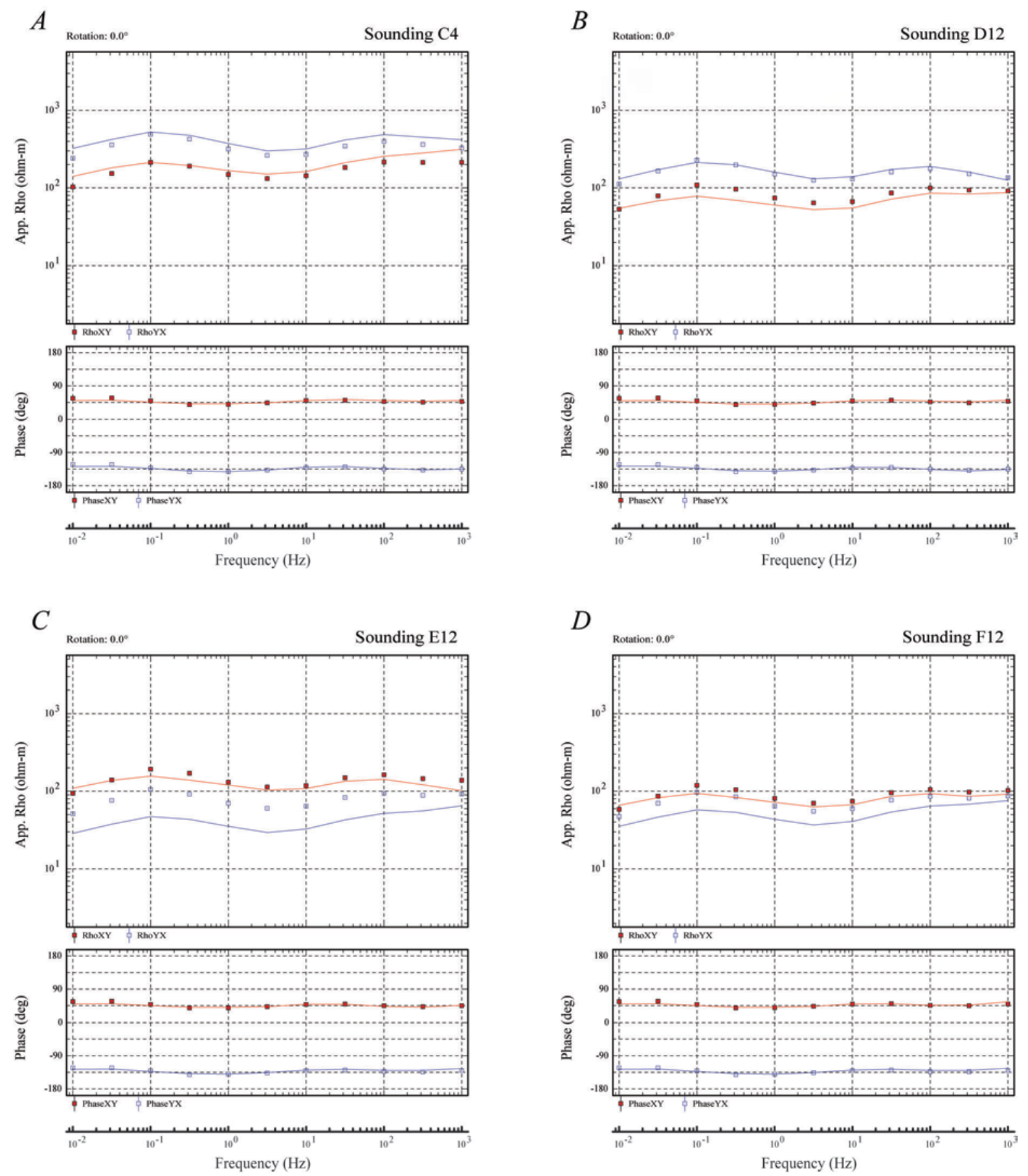

Figure 6. Three-dimensional (3-D) inversion model (400 ohm-meters [ohm-m] initial resistivity, 250-meters [m] $X Y$ cell size) resistivity and phase data. App Rho is apparent resistivity. Phase is in degrees (deg). Red and blue lines are the 3-D computed $X Y$ and $Y X$ inversion curves, respectively. Red and blue square symbols are the 3-D simulated observed $X Y$ and $Y X$ data, respectively. A) Magnetotelluric station C4. B) Magnetotelluric station D12. C) Magnetotelluric station E12. D) Magnetotelluric station F12. (Hz, hertz)

The inversion of the resistivity model using the same mesh grid and station spacing as the homogeneous $400 \mathrm{ohm}-\mathrm{m}$ volume model, but employing an initial homogeneous $100 \mathrm{ohm}-\mathrm{m}$ volume 
model ("100-c" in table 1), resulted in a decrease in the RMS error from 2.4573 to an RMS error of 0.3777 after four iterations. Figure 7 illustrates the 3-D resistivity inversion result. The simulated observed magnetotelluric data and the computed magnetotelluric response of the fourth inversion iteration are shown in figure 8. Although there was an improved misfit to the static shift magnitude of station F12 (0.006-delta) (table 1), the static shift magnitude misfits (table 1) for stations C4 and D12 were worse (0.078- and 0.019-delta, respectively) (table 1) when compared with the homogeneous 400 ohm-m volume misfit. The static shift magnitude for station E12 was nearly equivalent (0.024delta) (table 1). The surface layer resistivity was generally underestimated for the more resistive structures (compare fig. $1 A$ with fig. $7 A$ ).
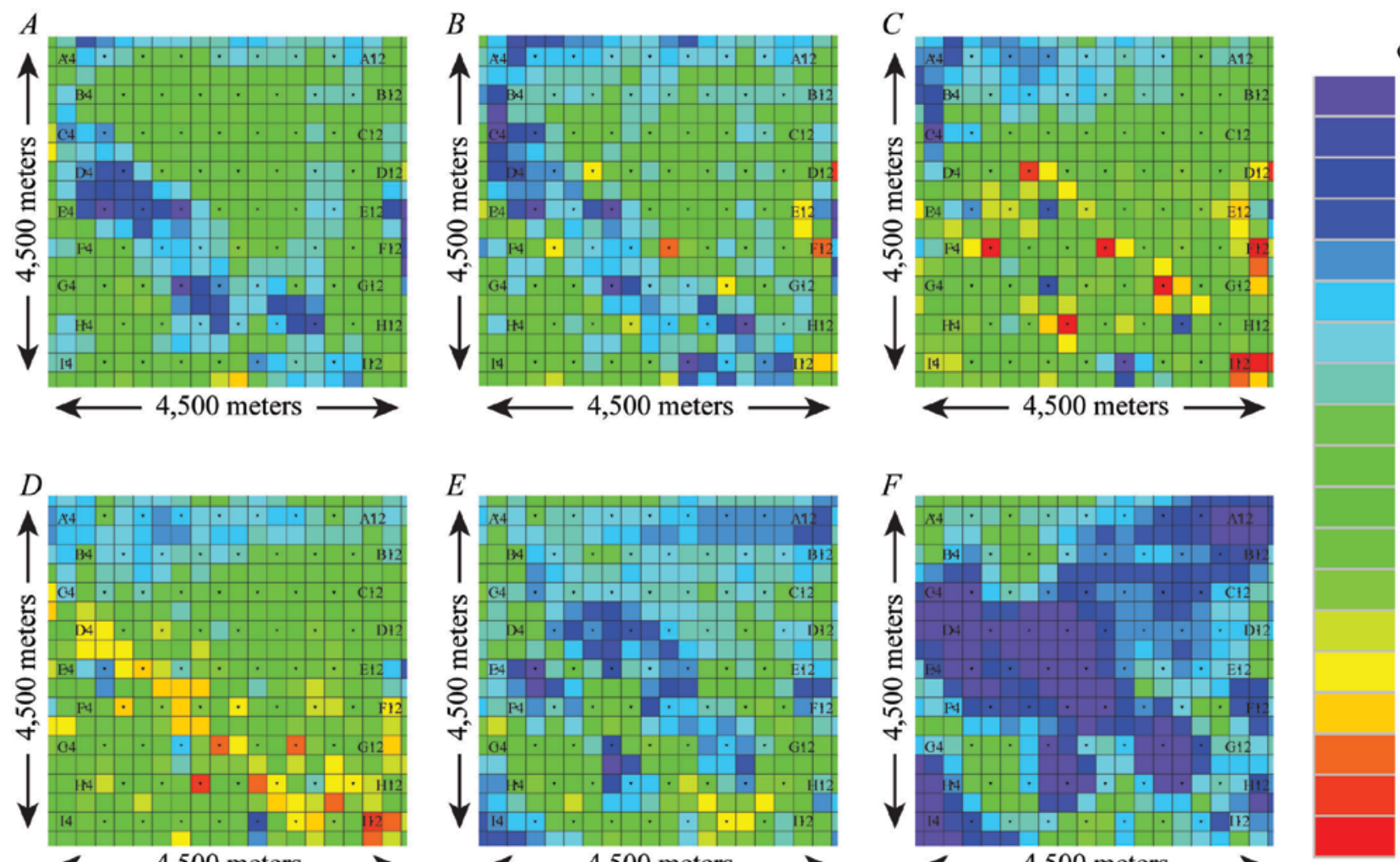

ohm-m 483
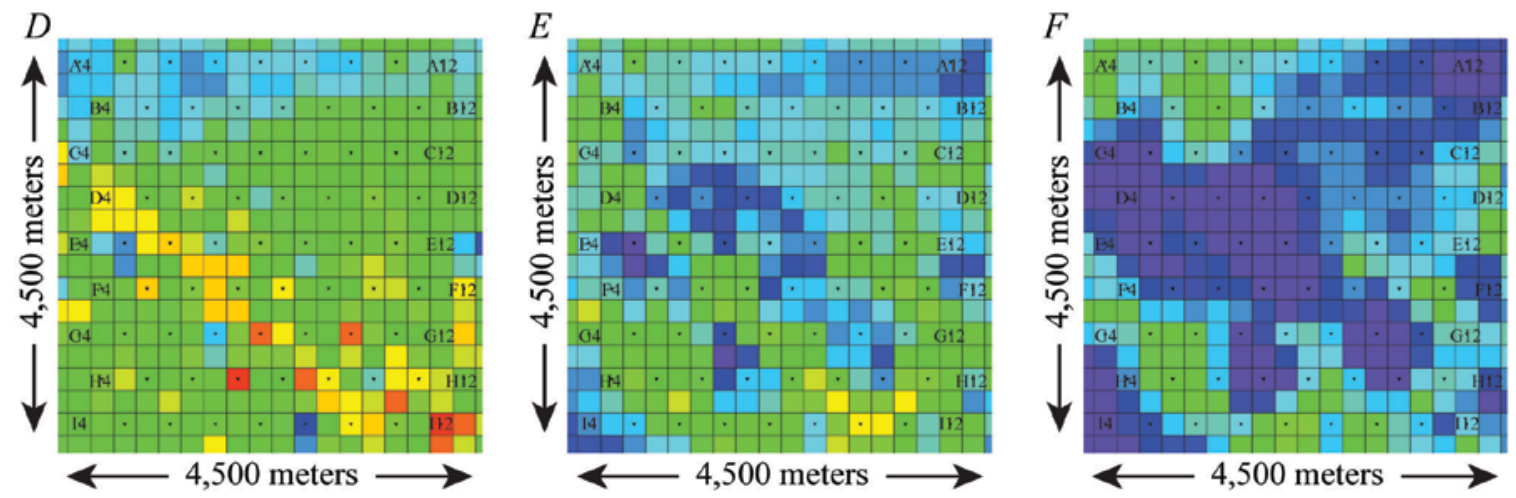

Figure 7. Three-dimensional inversion model (100 ohm-meters [ohm-m] initial resistivity, 250-meter [m] XY cell size) depth slices. Black labels within cells are simulated magnetotelluric stations. A) 0 - to $50-\mathrm{m}$ depth. B) 50 - to 100-m depth. C) 100- to 150-m depth. D) 150- to 200-m depth. E) 200- to 250-m depth. F) 250- to 300-m depth. 

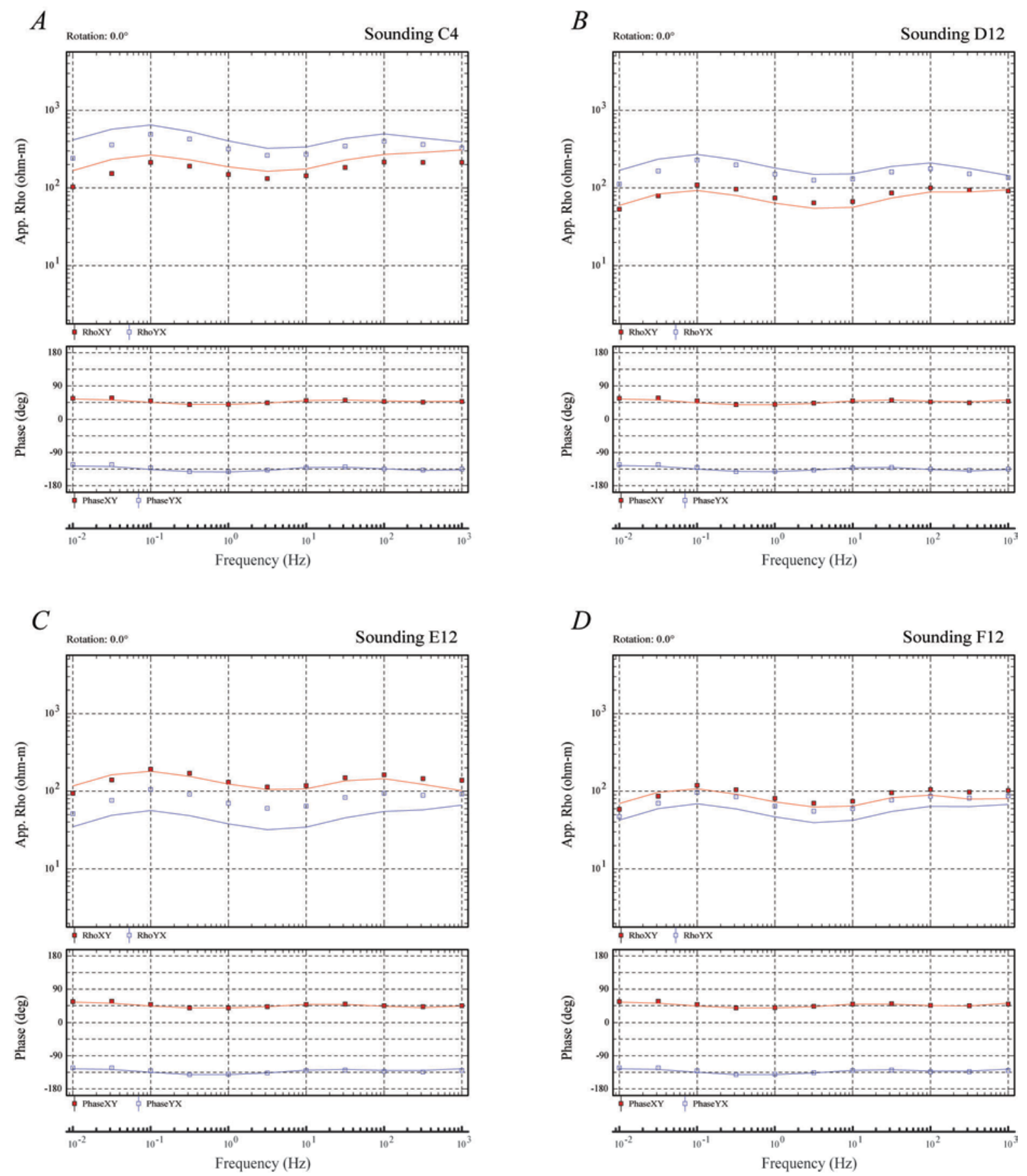

Figure 8. Three-dimensional inversion model (100 ohm-meters [ohm-m] initial resistivity, 250-meter XY cell size) resistivity and phase data. App Rho is apparent resistivity. Phase is in degrees (deg). Red and blue lines are the 3-D computed $X Y$ and $Y X$ inversion curves, respectively. Red and blue square symbols are the 3-D simulated observed $X Y$ and $Y X$ data, respectively. A) Magnetotelluric station C4. B) Magnetotelluric station D12. C) Magnetotelluric station E12. D) Magnetotelluric station F12. (Hz, hertz)

In the "known" fine-mesh model (fig. 3), magnetotelluric stations C4, D12, E12, and F12 (fig. 4) have the largest local 3-D distortion in the XY and YX components (0.257-, 0.276-, 0.293-, and 0.094- 
decade, respectively) (table 1). The inversion of the resistivity model ("100-f" in table 1) with the smaller cell size $(50 \mathrm{~m}$ by $50 \mathrm{~m})$ and the smaller station spacing $(100 \mathrm{~m})$, resulted in a decrease in the RMS error from 1.3359 for the initial homogenous $100 \mathrm{ohm}-\mathrm{m}$ volume to an RMS error of 0.2558 after four iterations. Figure 9 illustrates the 3-D resistivity inversion result. The simulated observed magnetotelluric data and the computed magnetotelluric response of the fourth inversion iteration are shown in figure 10. Although there was an improved misfit to the static shift of station D12 (0.007delta) (table 1) (fig. 10B) compared to the static shift of the homogeneous $100 \mathrm{ohm}-\mathrm{m}$ volume model, the static shift magnitude misfit (table 1) for stations E12 and F12 was worse (0.049- and 0.010-delta, respectively) (table 1). The static shift magnitude for station $\mathrm{C} 4$ was nearly equivalent (0.079-delta) (table 1), but the near-surface second layer resistivity was underestimated (fig. $9 A$ ). Much of the resistivity is underestimated for the second layer (compare fig. $3 B$ to fig. $9 B$ ). The underestimated resistivities may be caused by a combination of using an initial model volume resistivity that was too low and over-smoothing by the default inversion parameters. This combination hindered the inversion's recovery of the shallow layer resistivities. The $400 \mathrm{ohm}-\mathrm{m}$ initial model inversion was not affected as severely from underestimated resistivities in the shallow layers (compare fig. $1 B$ with fig. $5 B$ ). Instead, the initial model volume resistivity may have been too high resulting in an overestimate of the shallow resistivities.
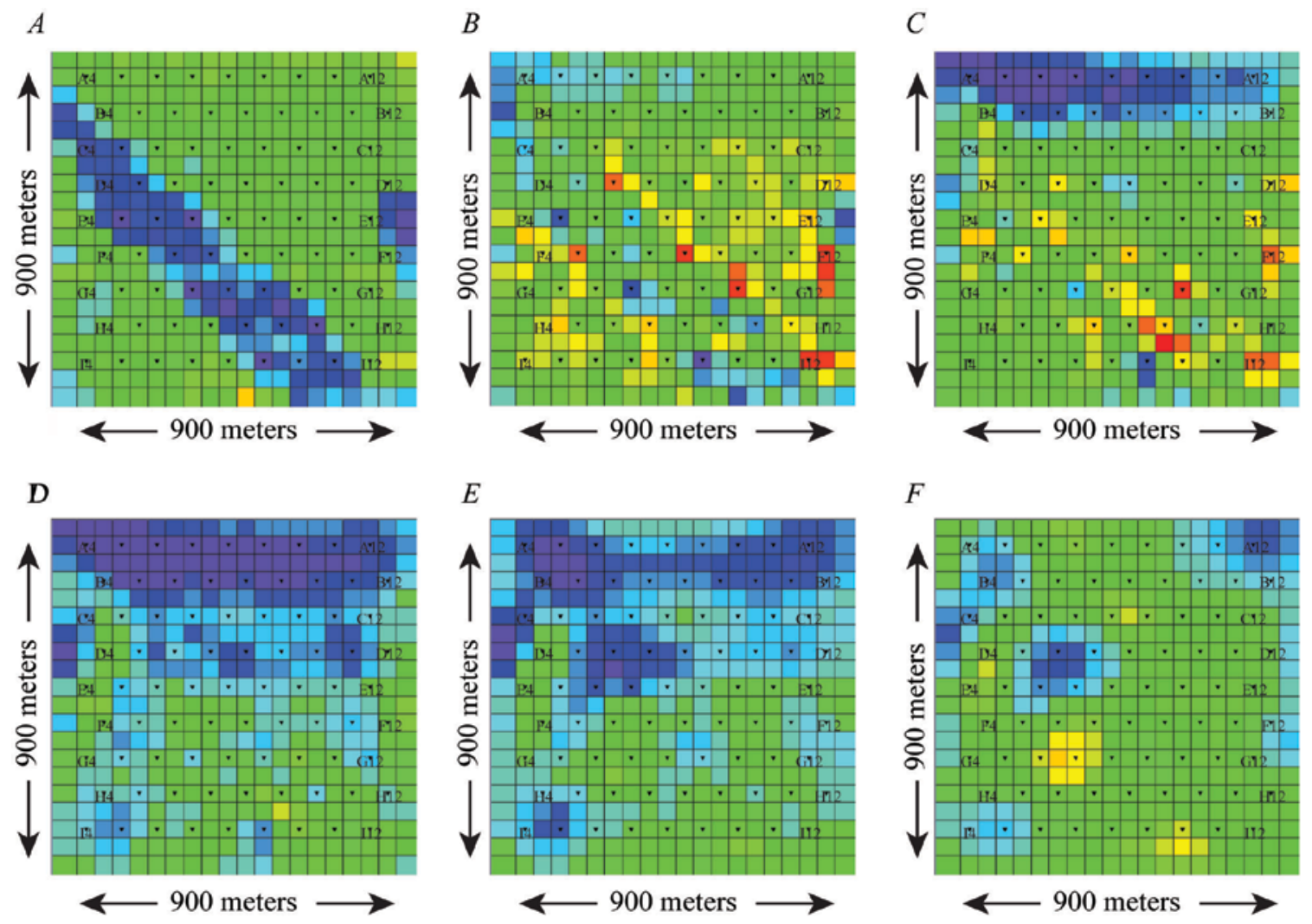

ohm-m

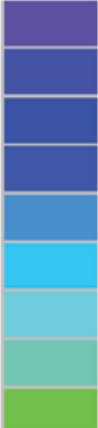

Figure 9. Three-dimensional inversion model (100 ohm-meters [ohm-m] initial resistivity, 50-meter [m] XY cell size) depth slices. Black labels within cells are simulated magnetotelluric stations. A) 0- to 50-m depth. B) 50- to 100-m depth. C) 100- to 150-m depth. D) 150- to 200-m depth. E) 200- to 250-m depth. F) 250- to 300-m depth. 

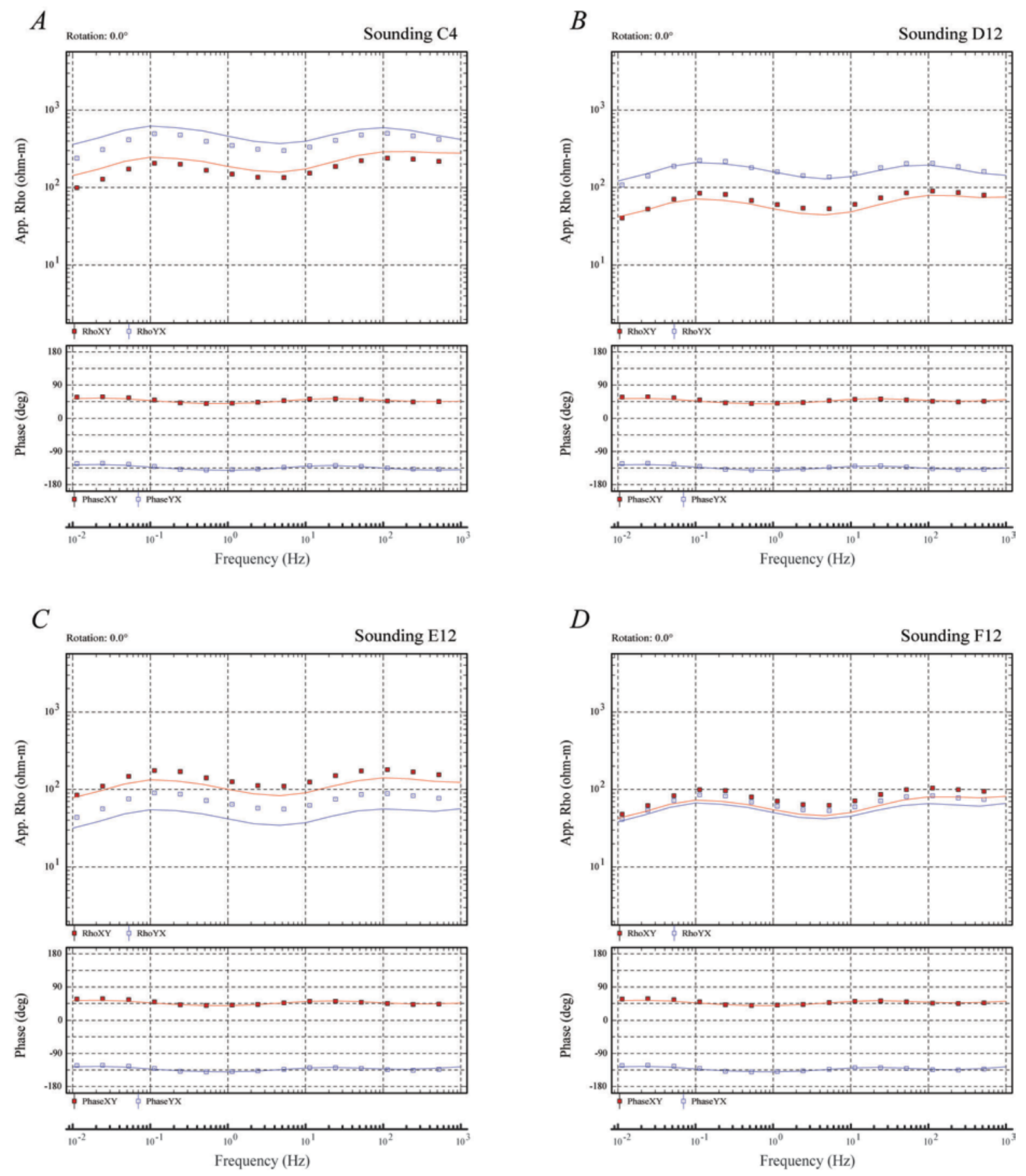

Figure 10. Three-dimensional inversion model (100 ohm-meters [ohm-m] initial resistivity, 50-meter XY cell size) resistivity and phase data. App Rho is apparent resistivity. Phase is in degrees (deg). Red and blue lines are the 3-D computed $X Y$ and $Y X$ inversion curves, respectively. Red and blue square symbols are the 3-D simulated observed $X Y$ and $Y X$ data, respectively. A) Magnetotelluric station C4. B) Magnetotelluric station D12. C) Magnetotelluric station E12. D) Magnetotelluric station F12. (Hz, hertz)

The inversion of the smaller-cell size resistivity model using only frequencies above 100 hertz ("High" in table 1) resulted in a decrease in the RMS error from 1.2158 for the initial homogenous 
$100 \mathrm{ohm}-\mathrm{m}$ volume to an RMS error of 0.5932 after 15 iterations. Figure 11 illustrates the 3-D resistivity inversion result. The simulated observed magnetotelluric data and the computed magnetotelluric response of the 15th inversion iteration are shown in figure 12. Although the static shift sense (XY $>Y X$ or $X Y<Y X)$ of each station was correct (fig. 12), the static shift misfit was not only worse for stations C4, D12, E12, and F12 (0.230-, 0.203-, 0.133-, and 0.077-delta, respectively) (table 1) but the near-surface layer resistivity was also underestimated (compare fig. $3 \mathrm{~A}$ with fig. $11 \mathrm{~A}$ ). Much of the resistivity is underestimated for the shallow layers (compare fig. 3 to fig. 11). The underestimated resistivities of the shallow layers is probably due to several reasons in combination: using an initial model volume resistivity that was too low, over-smoothing by the default inversion parameters, and a smaller skin depth from inverting only the higher frequencies.
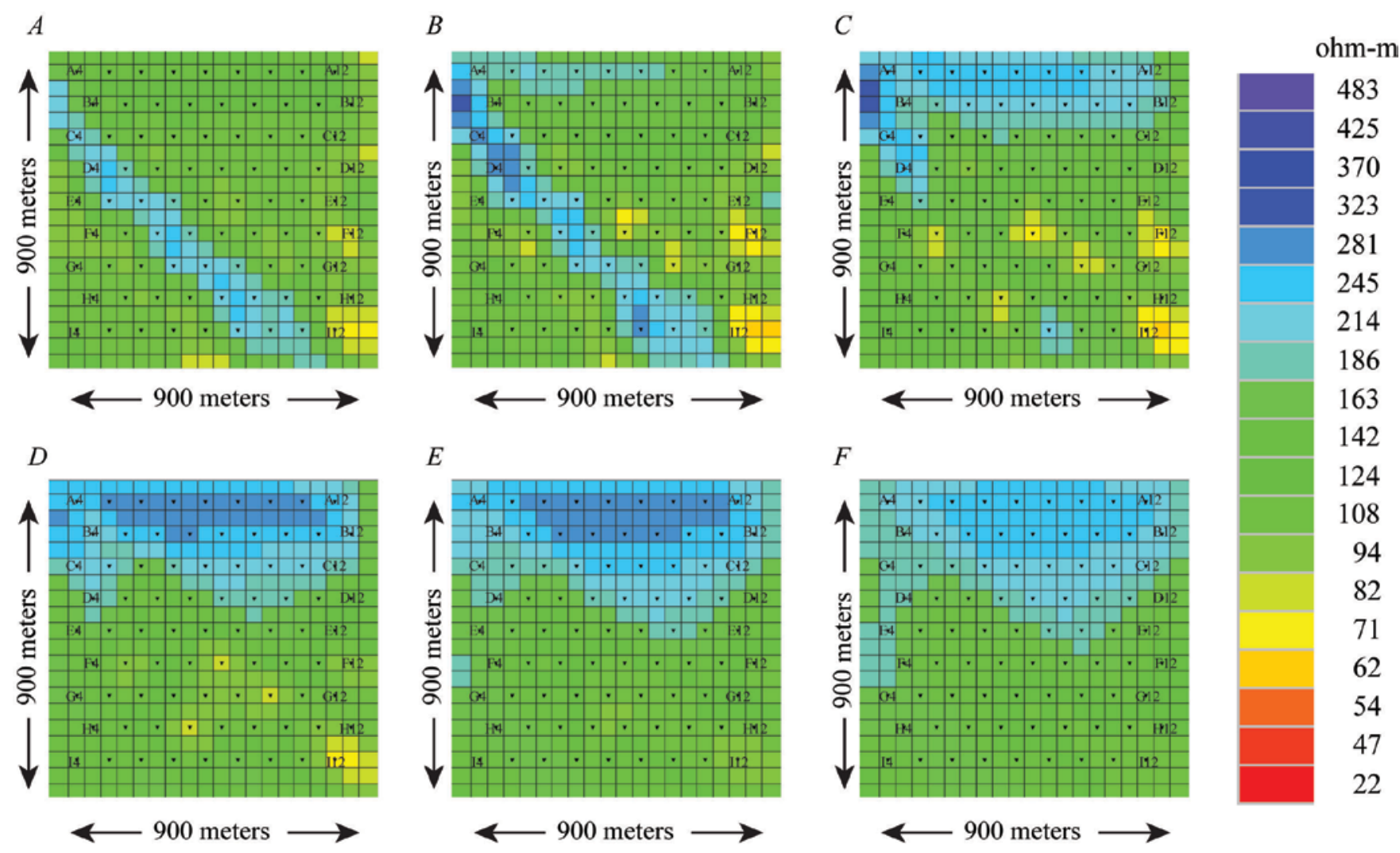

Figure 11. Three-dimensional high-frequency inversion model (100 ohm-meters [ohm-m] initial resistivity, 50-meter [m] XY cell size) depth slices. Black labels within cells are simulated magnetotelluric stations. A) 0- to 50$\mathrm{m}$ depth. B) 50- to 100-m depth. C) 100- to 150-m depth. D) 150- to 200-m depth. E) 200- to 250-m depth. F) 250to $300-m$ depth. 

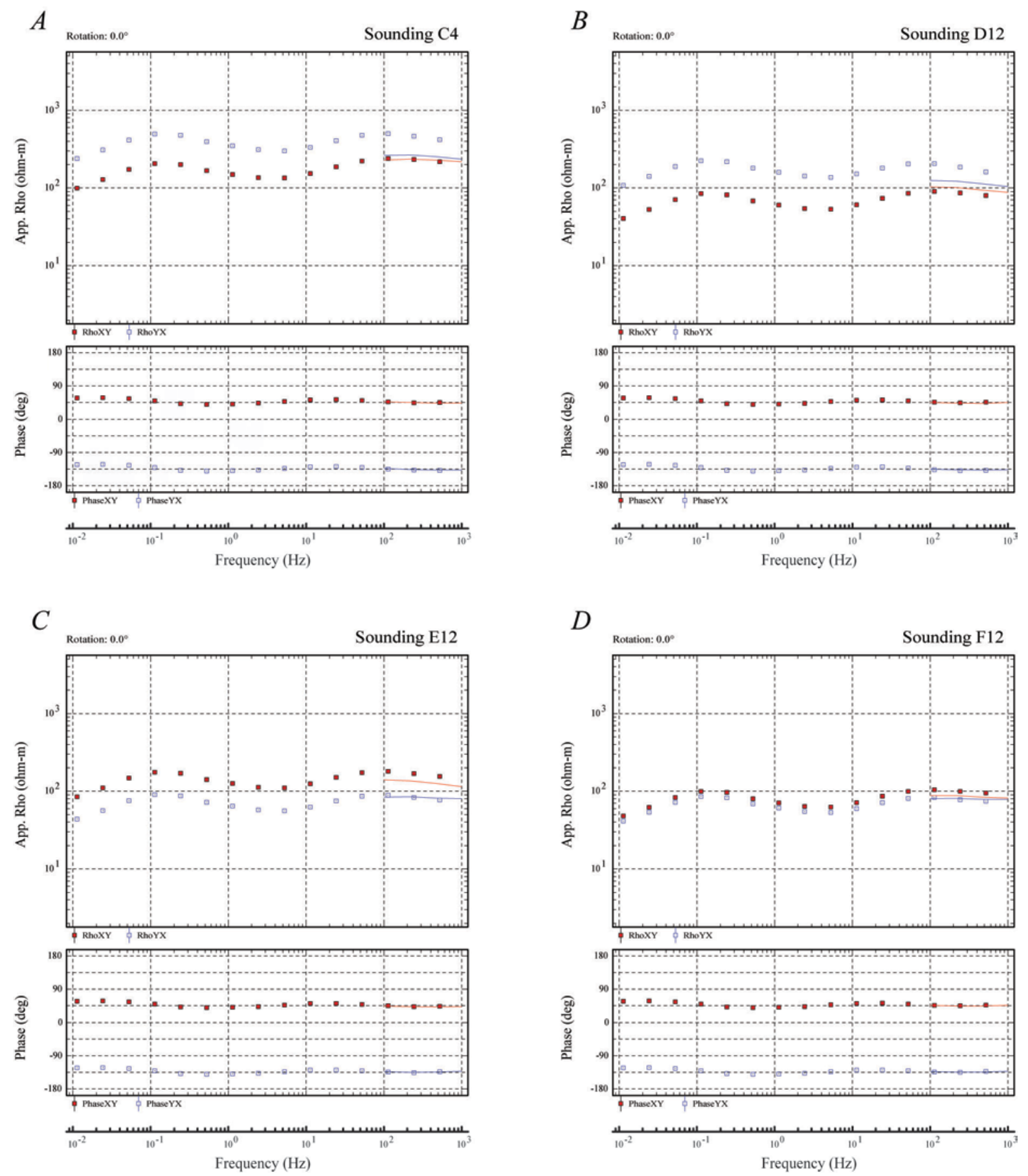

Figure 12. Three-dimensional (3-D) high-frequency inversion model (100 ohm-meters [ohm-m] initial resistivity, 50-meter XY cell size) resistivity and phase data. App Rho is apparent resistivity. Phase is in degrees (deg). Red and blue lines are the 3-D computed $X Y$ and $Y X$ inversion curves, respectively. Red and blue square symbols are the 3-D simulated observed $X Y$ and $Y X$ data, respectively. A) Magnetotelluric station $C 4$. B) Magnetotelluric station D12. C) Magnetotelluric station E12. D) Magnetotelluric station F12. (Hz, hertz)

The inversion of the smaller-cell size resistivity model using the high-frequency inversion as the initial model ("A priori" in table 1) resulted in a decrease in the RMS error from 0.8796 for the initial 
high-frequency inversion model to an RMS error of 0.2704 after five iterations. Figure 13 illustrates the 3-D resistivity inversion result. The simulated observed magnetotelluric data and the computed magnetotelluric response of the fifth inversion iteration are shown in figure 14. The static shift magnitudes were overestimated for all four of the 3-D distorted stations (0.046-, 0.031-, 0.097-, and 0.008 -delta, respectively) (table 1 and fig. 14). The resistivity is underestimated for the near-surface layer, but there is a mix of under and overestimations for the other shallow layers (fig. 13).
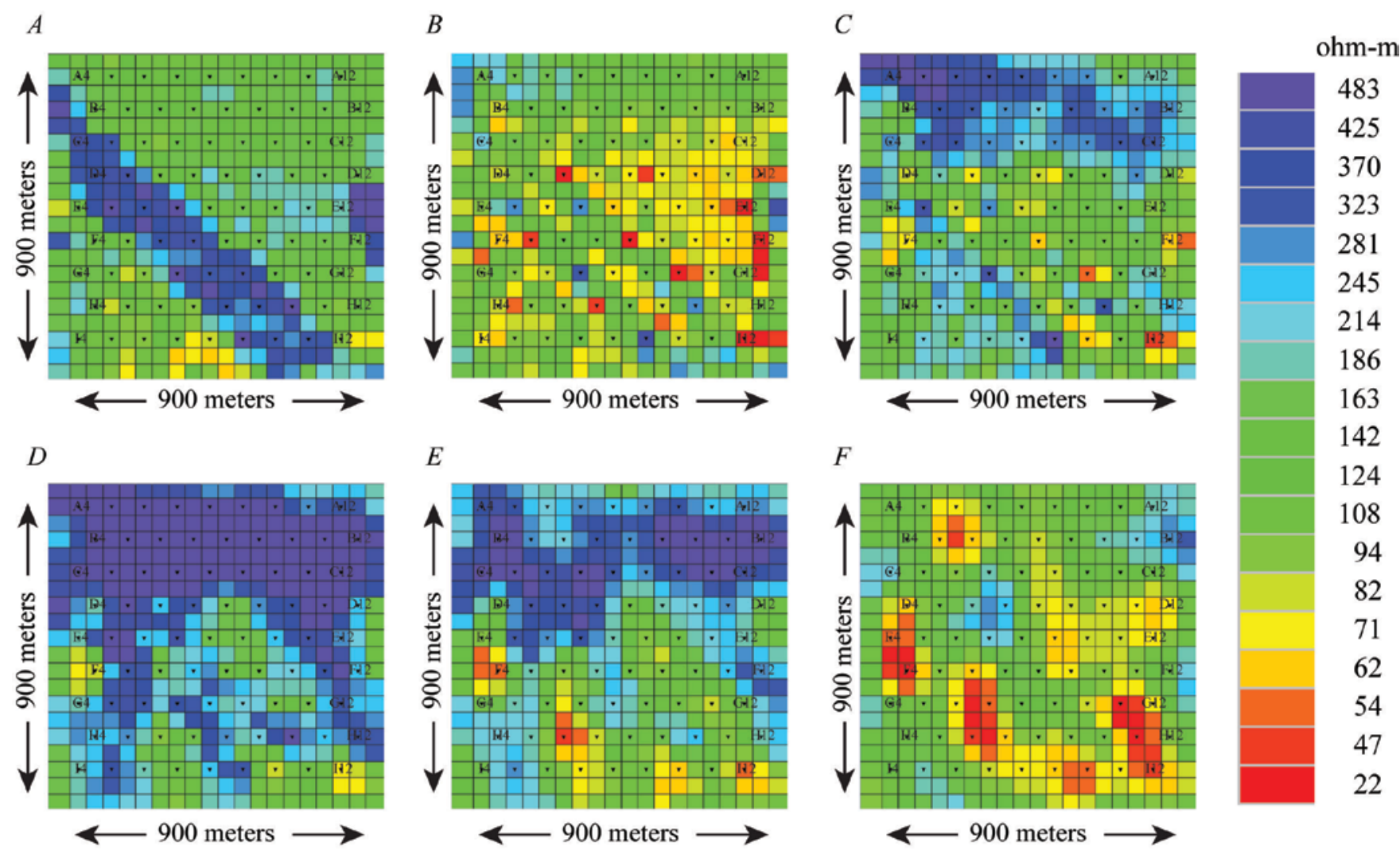

Figure 13. Three-dimensional a priori inversion model (50-meter [m] XY cell size) depth slices. Black labels within cells are simulated magnetotelluric stations. A) 0- to 50-m depth. B) 50- to 100-m depth. C) 100- to 150-m depth. D) 150- to 200-m depth. E) 200- to 250-m depth. F) 250- to 300-m depth. (ohm-m, ohm-meters) 

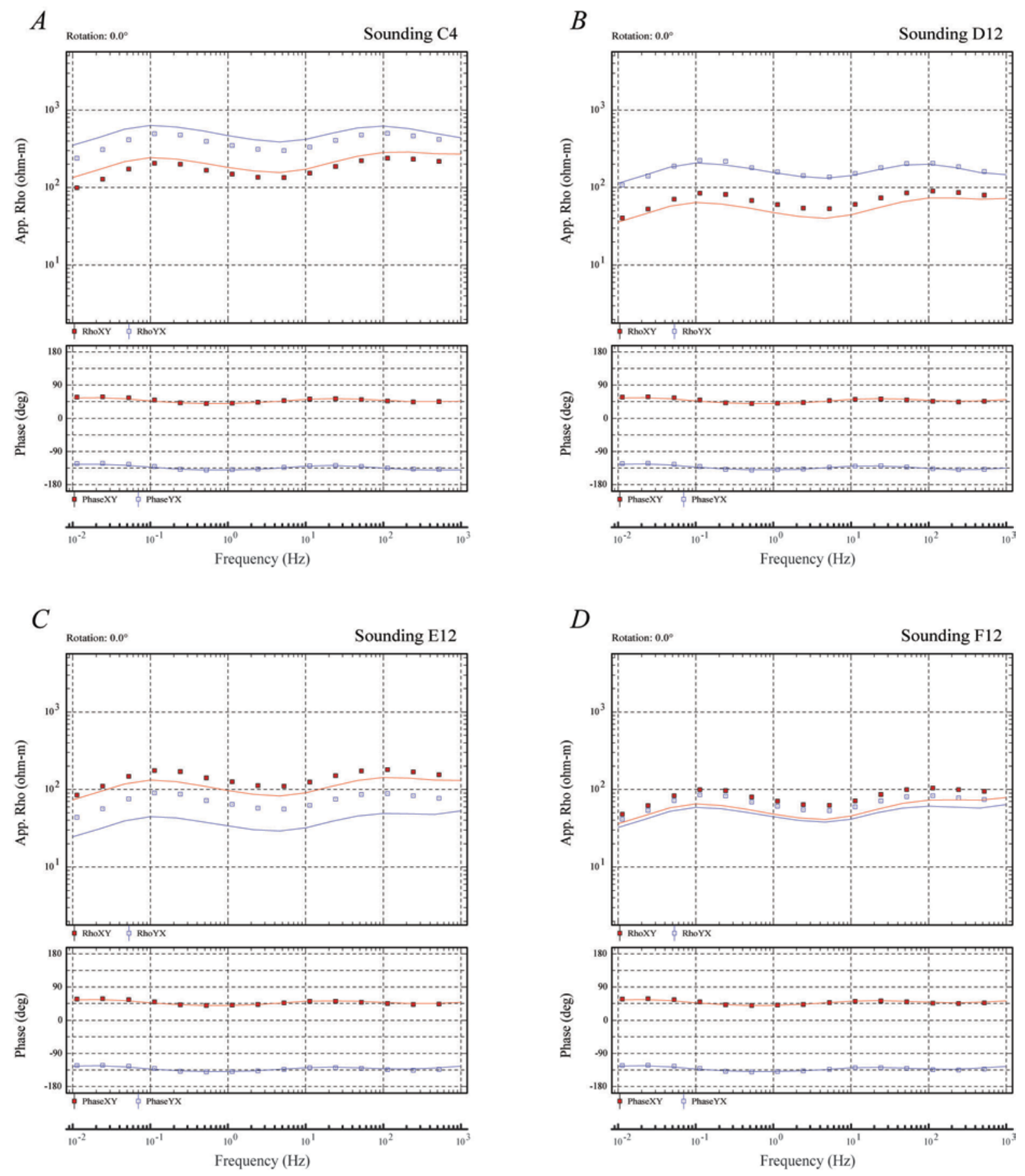

Figure 14. Three-dimensional (3-D) a priori inversion model (50-meter XY cell size) resistivity and phase data. App Rho is apparent resistivity. Phase is in degrees (deg). Red and blue lines are the 3-D computed XY and YX inversion curves, respectively. Red and blue square symbols are the 3-D simulated observed $X Y$ and $Y X$ data, respectively. A) Magnetotelluric station C4. B) Magnetotelluric station D12. C) Magnetotelluric station E12. D) Magnetotelluric station F12. ( $\mathrm{Hz}$, hertz)

The inversion of the smaller-cell size resistivity model using the less-smooth model covariance time step and the smaller Lagrange multiplier ("Less" in table 1) resulted in a decrease in the RMS error 
from 1.3359 for the initial homogenous $100 \mathrm{ohm}-\mathrm{m}$ volume to 0.3360 after four iterations (the fifth iteration resulted in an increased RMS error). Figure 15 illustrates the 3-D resistivity inversion result. The simulated observed magnetotelluric data and the computed magnetotelluric response of the fourth inversion iteration are shown in figure 16. The static shift magnitudes were overestimated for all of the 3 -D distorted stations (0.042-, 0.060-, 0.140-, and 0.055-delta, respectively) (table 1 and fig. 16). Much of the resistivity is underestimated for the shallow layers (fig. 15).
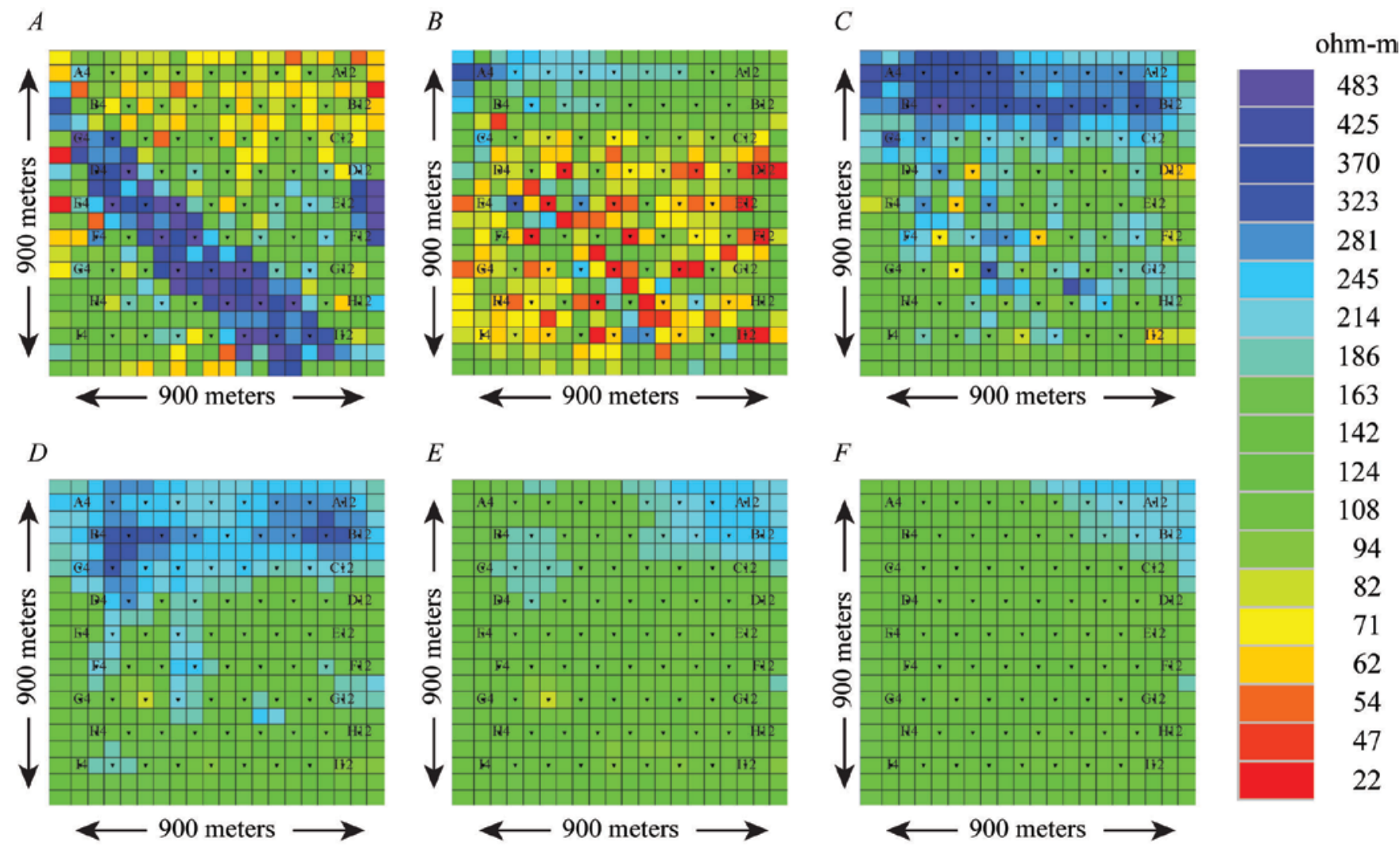

Figure 15. Three-dimensional less smooth inversion model (50-meter [m] XY cell size) depth slices. Black labels within cells are simulated magnetotelluric stations. A) 0- to 50-m depth. B) 50- to 100-m depth. C) 100- to 150-m depth. D) 150- to 200-m depth. E) 200- to 250-m depth. F) 250- to 300-m depth. (ohm-m, ohm-meters) 

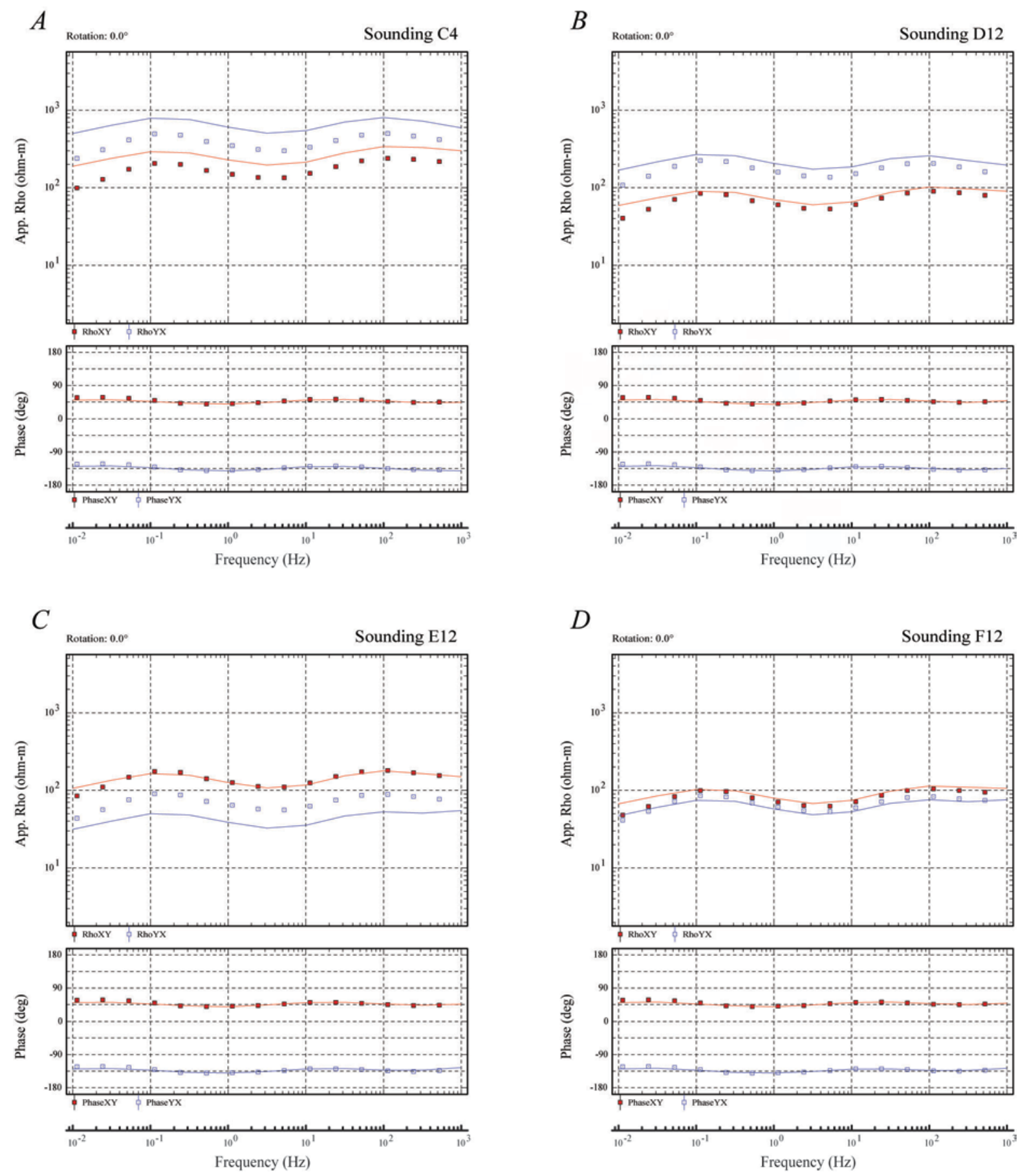

Figure 16. Three-dimensional (3-D) less smooth inversion model (50-meter XY cell size) resistivity and phase data. App Rho is apparent resistivity. Phase is in degrees (deg). Red and blue lines are the 3-D computed XY and $Y X$ inversion curves, respectively. Red and blue square symbols are the 3-D simulated observed $X Y$ and $Y X$ data, respectively. A) Magnetotelluric station C4. B) Magnetotelluric station D12. C) Magnetotelluric station E12. D) Magnetotelluric station F12. (Hz, hertz; ohm-m, ohm-meters)

The inversion approach that produced the lowest misfit to the various local 3-D distortions was the initial inversion with the larger cell size and station spacing (table 1). The smaller cell size and 
station spacing inversion produced the next best misfits. Worse static shift magnitude misfits were produced by the inversion approach that used a semiautomatic approach of first accounting for the static shift using the highest frequencies and then using the resulting inversion as the initial model for a fullfrequency inversion. The worst approach to account for local 3-D distortion was the inversion that employed a less smooth model covariance time step and the smaller Lagrange multiplier; this approach also produced the largest overestimation of the static shift magnitude (table 1) and the highest amount of model artifacts in the near-surface layer (fig. 15A).

\section{Conclusions}

Three-dimensional (3-D) distortion needs to be accounted for when modeling magnetotelluric data. In two-dimensional inversions, the inclusion of the vertical transfer function (the Tipper) helps diminish the effects of local 3-D distortion that strongly affects the impedance tensor, but not all surveys include the vertical magnetic field measurements. In 3-D inversions, a solution for determining the local two-dimensional distortion when the regional resistivity structure is 3-D has been previously studied, but the case of local 3-D distortion over 3-D regional structure has remained elusive. This report summarized the results of 3-D resistivity inversion simulations that were performed to account for local 3-D distortion in the presence of 3-D regional structure without any a priori information on the actual 3-D distribution of the known subsurface geology.

The inversion approach that produced the lowest misfit to the various local 3-D distortions was an inversion with a more resistive initial volume. Smaller cell sizes and station spacings did not improve the static shift misfits. Worse static shift misfits were produced by the inversion approach that used a semiautomatic approach of first accounting for the static shift using the highest frequencies and then using the resulting inversion as the initial model for a full-frequency inversion. Employing a lesssmooth model covariance-time step and the smaller Lagrange multiplier produced an overestimation of the static shift magnitude and the highest amount of model artifacts in the near-surface layer.

Additional testing would help determine whether 3-D inversion using the modeling program WSINV3DMT can account for the 3-D regional distortion in the presence of local 3-D distortion. Further 3-D inversions could be tested by building a synthetic model using the best misfit, first-layer inverted resistivities (either free or frozen) merged with a homogeneous volume for the deeper layers.

\section{Acknowledgments}

U.S. Geological Survey reviewers Paul Bedrosian and Beth Burton provided constructive reviews and helpful comments for this report. This work was supported by the Mineral Resources Program of the U.S. Geological Survey.

\section{References Cited}

Avdeev, Dmitry, and Avdeeva, Anna, 2009, 3D magnetotelluric inversion using a limited-memory quasi-Newton optimization: Geophysics, v. 74, no. 3, p. F45-F57, accessed January 8, 2013, at https://doi.org/10.1190/1.3114023.

Bendat, J.S., and Piersol, A.G., 1971, Random data-Analysis and measurement procedures: New York, Wiley Interscience, $407 \mathrm{p}$.

Berdichevsky, M.N., Dmitriev, V.I, Golubtsova, N.S., and Pushkarev, P.Yu., 2003, Magnetovariation sounding-New possibilities: Izvestia, Phys. Solid Earth, v. 39, no. 9, p. 701-727, accessed October 21, 2015, at https://www.researchgate.net/publication/261502038_Magnetovariational_sounding_New_possibilities. 
Dobrin, M.D., and Savit, C.H., 1988, Introduction to geophysical prospecting (4th ed.): New York, McGraw-Hill, 867 p.

Egbert, G.D., and Kelbert, Anna, 2012, Computational recipes for electromagnetic inverse problems: Geophysical Journal International, v. 189, no. 1, p. 251-267, accessed April 17, 2014, at https://doi.org/10.1111/j.1365-246X.2011.05347.x.

Fenelon, J.M., Sweetkind, D.S., and Laczniak, R.J., 2010, Groundwater flow systems at the Nevada Test Site, Nevada - A synthesis of potentiometric contours, hydrostratigraphy, and geologic structures: U.S. Geological Survey Professional Paper 1771, 54 p., 6 pls., accessed March 2, 2010, at http://pubs.usgs.gov/pp/1771/.

Gribenko, A.V., and Zhdanov, M.S., 2007, Rigorous 3D inversion of marine CSEM data based on the integral equation method: Geophysics, v. 72, no. 2, p. WA73-WA84, accessed December 23, 2016, at https://doi.org/10.1190/1.2435712.

Gribenko, A.V, Green, A.M., Cuma, Martin, and Zhdanov, M.S., 2010, Efficient 3D inversion of MT data using integral equations method and the receiver footprint approach-Application to the largescale inversion of the EarthScope MT data: Society of Exploration Geophysicists, SEG Technical Program Expanded Abstracts 2010, p. 644-649, accessed December 23, 2016, at https://doi.org/10.1190/1.3513865.

Hallenburg, J.K., 1998, Non-hydrocarbon methods of geophysical formation evaluation: Boca Raton, Fla., Lewis Publishers, 265 p.

Han, Nuree, Nam, M.J., Kim H.J., Lee, T.J., Song, Yoonho, and Suh, J.H., 2008, Efficient threedimensional inversion of magnetotelluric data using approximate sensitivities: Geophysical Journal International, v. 175, no. 2, p. 477-485, accessed Jan 8, 2013, at https://doi.org/10.1111/j.1365246X.2008.03894.x.

Hearst, J.R., and Nelson, P.H., 1985, Well logging for physical properties: New York, McGraw-Hill, $571 \mathrm{p}$.

Jiracek, G.R., 1990, Near-surface and topographic distortions in electromagnetic induction: Surveys in Geophysics, v. 11, no. 2, p. 163-203, accessed January 6, 2016, at https://doi.org/10.1007/BF01901659.

Jones, A.G., 2011, Three-dimensional galvanic distortion of three-dimensional regional conductivity structures - Comment on "Three-dimensional joint inversion for magnetotelluric resistivity and static shift distributions in complex media” by Yutaka Sasaki and Max A. Meju: Journal of Geophysical Research-Solid Earth, v. 116, no. B12, accessed January 8, 2013, at https://doi.org/10.1029/2011JB008665.

Jones, A.G., 2012, Distortion of magnetotelluric data: its identification and removal, chap. 6 of Chave, A.D., and Jones, A.G., eds., The Magnetotelluric Method - Theory and practice: Cambridge University Press, p. 219-302.

Kelbert, Anna, Meqbel, Naser, Egbert, G.D., and Tandon, Kush, 2014, ModEM-A modular system for inversion of electromagnetic geophysical data: Computers and Geoscience, v. 66, p. 40-53, accessed December 23, 2016, at https://doi.org/10.1016/j.cageo.2014.01.010.

Keller, G.V., 1987, Rock and mineral properties, in Nabighian, M.N., ed., Electromagnetic methods in applied geophysics theory: Tulsa, Okla., Society of Exploration Geophysicists, v. 1, p. 13-51.

Keller, G.V., 1989, Electrical properties, in Carmichael, R.S., ed., Practical handbook of physical properties of rocks and minerals: Boca Raton, Fla., CRC Press, p. 359-427.

Keller, G.V., and Frischknecht, F.C., 1966, Electrical methods in geophysical prospecting: Oxford, Pergamon Press, Inc., 519 p. 
Ledo, Juanjo, Queralt, Pilar, and Paous, Jaume, 1998, Effects of galvanic distortion on magnetotelluric data over a three-dimensional regional structure: Geophysical Journal International, v. 132, no. 2, p. 295-301, accessed January 29, 2014, at https://doi.org/10.1046/j.1365-246x.1998.00417.x.

Mackie, R.L., and Madden, T.R., 1993, Three-dimensional magnetotelluric inversion using conjugate gradients: Geophysical Journal International, v. 115, no. 1, p. 215-229, accessed December 23, 2016, at https://doi.org/10.1111/j.1365-246X.1993.tb05600.x.

Mackie, R.L., Smith, J.T., and Madden, T.R., 1994, Three-dimensional electromagnetic modeling using finite difference equations-The magnetotelluric example: Radio Science, v. 29, p. 923-935, accessed December 23, 2016, at https://doi.org/10.1029/94RS00326.

Mackie, R.L., Watts, M.D., and Rodi, William, 2007, Joint 3D inversion of marine CSEM and MT data: Society of Exploration Geophysicists, SEG Technical Program Expanded Abstracts 2007, p. 574-578, accessed December 23, 2016, at https://doi.org/10.1190/1.2792486.

Miensopust, M.P., 2010, Multidimensional magnetotellurics-A 2D case study and a 3D approach to simultaneously invert for resistivity structure and distortion parameters: Galway, Ireland, National University of Ireland, Ph.D. thesis, $353 \mathrm{p}$.

Newman, G.A., and Alumbaugh, D.L., 2000, Three-dimensional magnetotelluric inversion using nonlinear conjugate gradients: Geophysical Journal International, v. 140, no. 2, p.410-424, accessed December 23, 2016, at https://doi.org/10.1046/j.1365-246x.2000.00007.x.

Palacky, G.J., 1987, Resistivity characteristics of geologic targets, in Nabighian, M.N., ed., Electromagnetic methods in applied geophysics - Volume 1, Theory: Tulsa, Okla., Society of Exploration Geophysicists, p. 53-129.

Rodriguez, B.D., and Sweetkind, D.S., 2015, Obtaining valid geologic models from 3-D resistivity inversion of magnetotelluric data at Pahute Mesa, Nevada: U.S. Geological Survey Open-File Report 2015-1019, 104 p, accessed February 27, 2015, at https://doi.org/10.3133/ofr20151019.

Sasaki, Yutaka, 2001, Full 3-D inversion of electromagnetic data on PC: Journal of Applied Geophysics, v. 46, no. 1, p. 45-54, accessed December 23, 2016, at https://doi.org/10.1016/S09269851(00)00038-0.

Sasaki, Yutaka, 2004, Three-dimensional inversion of static-shifted magnetotelluric data: Earth, Planets, and Space, v. 56, no. 2, p. 239-248, accessed May 30, 2012, at https://doi.org/10.1186/BF03353406.

Sasaki, Yutaka, and Meju, M.A., 2006, Three-dimensional joint inversion for magnetotelluric resistivity and static shift distributions in complex media: Journal of Geophysical Research, Solid Earth, v. 111, no. B05101, p. 1-11, accessed January 8, 2013, at https://doi.org/10.1029/2005JB004009.

Siripunvaraporn, Weerachai, Egbert, G.D., Lenbury, Yongwimon, and Uyeshima, Makoto, 2005, Threedimensional magnetotelluric inversion-Data-space method: Physics of the Earth and Planetary Interiors, v. 150, p. 3-14, accessed November 16, 2010, at https://doi.org/10.1016/j.pepi.2004.08.023.

Siripunvaraporn, Weerachai, and Egbert, G.D., 2009, WSINV3DMT_-Vertical magnetic field transfer function inversion and parallel implementation: Physics of the Earth and Planetary Interiors, v. 173, no. 3-4, p. 317-329, accessed August 31, 2010, at https://doi.org/10.1016/j.pepi.2009.01.013.

Siripunvaraporn, Weerachai, and Sarakorn, Weerachai, 2011, An efficient data space conjugate gradient Occam's method for three-dimensional magnetotelluric inversion: Geophysical Journal International, v. 186, no. 2, p. 567-579, accessed January 8, 2013, at https://doi.org/10.1111/j.1365246x.2011.05079.x.

Siripunvaraporn, Weerachai, Uyeshima, Makoto, and Egbert, G.D., 2004, Three-dimensional inversion for network-magnetotelluric data: Earth, Planets, and Space, v. 56, no. 9, p. 893-902, accessed May 30, 2012, at https://doi.org/10.1186/BF03352536. 
Smith, J.T., and Booker, J.R., 1991, Rapid inversion of two- and three-dimensional magnetotelluric data: Journal of Geophysical Research, Solid Earth, v. 96, no. B3, p. 3905-3922, accessed December 23, 2016, at https://doi.org/10.1029/90JB02416.

Vozoff, Keeva, 1972, The magnetotelluric method in the exploration of sedimentary basins: Geophysics, v. 37, no. 1, p. 98-141, accessed December 10, 2010, at https://doi.org/10.1190/1.1440255.

Vozoff, Keeva, 1991, The magnetotelluric method, in Nabighian, M.N., Electromagnetic methods in applied geophysics: Tulsa, Okla., Society of Exploration Geophysicists, v. 2, pt. B, p. 641-711.

Weidelt, Peter, and Chave, A.D., 2012, The magnetotelluric response function, chap. 4 of Chave, A.D., and Jones, A.G., eds., The Magnetotelluric Method-Theory and practice: Cambridge University Press, p. 122-164.

Zhdanov, M.S., 2002, Geophysical inverse theory and regularization problems: Amsterdam, Elsevier, $609 \mathrm{p}$.

Zhdanov, M.S., Fang, Sheng, and Hursan, Gabor, 2000, Electromagnetic inversion using quasi-linear approximation: Geophysics, v. 65, no. 5, p. 1501-1513, accessed December 23, 2016, at https://doi.org/10.1190/1.1444839. 
ISSN 2331-1258 (online)

https://doi.org/10.3133/ofr20171007 